\title{
SELÇUKLULAR'DA RÜŞVET
}

\section{ERDOĞAN MERÇIL}

En eski dönemlerden itibaren toplumda görülen bir olay olan rüşvet alıp vermenin tarifine sözlüklerde pek rastlanmıyor. Şemseddîn Sami''nin rüșvet tarifi ki, bugünkü anlamına uygun düșmekte olup, șu şekildedir, "Bir memura haklı veya haksız bir iş gördürmek için verilen ücret veya hediye". Bir başka tarife göre"2, "rüşvet, yapturılmak istenen bir iște, kanun dıșı kolaylık sağlanması için bir kimseye mal veya para olarak sağlanan menfaat" dir. Bu tarife hediyeyi de eklersek genel anlamıla konumuza daha uygun düşmektedir.

Selçuklu dönemindeki rüşvet ile ilgili bir çalışma, Prof. Ahmet Mumcu $^{3}$ 'nun eserinde görülmektedir. Ancak bu çalışma Osmanlı Devleti'yle ilgilidir ve adı geçen eserde "Selçuklular'da Rüșvet" alt bașlığıyla ifade edilmiş kısa bir girişten öteye geçememektedir.

\section{Sultan Tuğrul Bey Dönemi}

Selçuklular ile ilgili tespit edebildiğimiz ilk rüșvet olayı, Tuğrul Bey döneminde geçmektedir. Arslan Besâsirî'nin isyanı sırasında Mervanoğlu Nasr el-Devle Ahmed Selçuklu itaatinden çıkıp, ona yardımda bulunmuştu. Bu nedenle ceza olarak onun memleketlerinin yağmalanması istenmiş, Tuğrul Bey de bunu haklı bulmuştu. Ancak Mervanoğlu, İstanbul'dan dönen Selçuklu elçisi Ebu'l-Fazl Nâsır b. İsmail el-Alevî ve Bizans elçisini yolların tehlikeli olduğu bahanesiyle yanında alıkoymuștu. Ebu'l-Fazl ise Selçuklu sultanına bir mektup yazarak durumu bildirmişti. Tuğrul Bey elçisinin bu mektubuyla vassalı Mervanoğlu'na karșı burukluk duymağa başladı. Buna mukabil Nasr el-Devle Ahmed sultanm eşine (Altuncan Hâtun) değerli armağanlarla bir hâdim gönderip ondan," sultandan kendisine bir zarar gelmemesi amacıyla yardım isteğinde bulundu”. Hâtun onun mesajını sultana arz edip Mervanoğlu için ricada bulundu. Tuğrul Bey ise, "Ben, Mer-

${ }^{1}$ Bk. Kamus-ı Türkî, Der Saadet h.1317, s.665.

${ }^{2}$ Bk. Örnekleriyle Türkçe Sözlük, Ankara 1996, Cilt 3, s.2384.

${ }^{3}$ Bk. Osmanl Devletinde Rüşvet (Özellikle Adli Rüşvet), Ankara 1969. Daha sonra 2005 deki üçüncü baskuda bir ilâve yapılmamışur. 
vanoğlu'nun beraberindeki hediyeleri almak amacıyla iki elçiyi hapsettiğini, düşmanlarımıza yardımda bulunduğunu ... öğrendim. Onun bu hareketleri gerçekten affedilmeyecek bir suçtur" dedi. Nasr el-Devle Ahmed'in Hâtun'a gönderdiği rüşvet bir işe yaramamıștı. Ancak Mervanoğlu, göz-altunda tutmakta olduğu iki elçiyi, yeni bir rüşvetle, beş yüz ipek elbise, at ve sair armağanla sultana gönderdi. Hatta onun için Emîr Hezaresb de sultandan şefaat diledi. Ancak Tuğrul Bey onun gönderdiği armağanlan (yani rüşveti) kabul etmeyip geri yollayarak Mervanoğlu konusundaki tutumunu israrla sürdürmüştü. Mervanoğlu daha sonra affi konusunda özel bir ulakla İbrahim Yınal'a başvurdu. İbrahim Yınal sultandan kendisi için şefaat girişiminde bulunacağını vaad etti ise de, onun Tuğrul Bey üzerinde etkili olup olmadığını bilemiyoruz. Nihayet Nasr el-Devle yüz bin dinar rüşvet karşılığında kendisini affettirmeğe muvaffak olmuştu ${ }^{4}$ (h.449/1057).

Tuğrul Bey döneminde başka bir rüşvet olayı Hoy şehrinde görülmektedir. Hoy şehri nal baha ile Selçuklulara teslim olduktan (Kasım 1062) üç gün sonra şehre giren Selçuklu Veziri Amid el-Mülk Kündürî buranın reisliğini halkın ileri gelenlerinden Ebû Sa'id b. Hamaveyh'e verdi. Ebû Sa'id ise aralarında düşmanlık bulunan şehrin eski reisi Yusuf b. Mengin'i on bin alun rüşvet karşılığında Amîd el-Mülk'ten teslim aldı ${ }^{5}$. Bu örnekte görüldüğü üzere rüșvet sadece işlerin bir menfaat karşılığında yapılmasıyla noktalanmayıp, insanların varlığını sona erdirebilecek sonuçlara da sebep oluyordu.

\section{Sultan Alp Arslan Dönemi}

Tuğrul Bey'in ölümüyle (1063), Vezir Amîd el-Mülk Çağrı Bey'in oğlu Süleyman adına hutbe okuttuktan sona Alp Arslan'a da bir mektup gönderip onu tehdit edip, korkutmağa çalışmış, hatta ona "Horasan yönetimiyle kanaat etmesini” bildirmişti. Alp Arslan Amîd el-Mülk'ün bu mektubunu kale

${ }^{4}$ Bk. Sevim, A., “Sıbt İbnü'l-Cevzî'nin Mir'atü'z-Zaman Fî Tarihi'l-Âyan Adlı eserindeki Selçuklularla İlgili Bilgiler I, Sultan Tuğrul Bey Dönemi", Belgeler, Sayı:22 Ankara 1997, s.21-22. 24; İbn el-Esîr, el-Kâmil fi't-Tarih, nşr. Tornberg, Beyrut 1979. IX, s.630; Trk. trc. çev. A. Özaydın, IX-XI, İstanbul 1987, IX, s.477; Yınanç. M.H., Türkiye Tarihi Selçuklular Devri. İstanbul 1944, s.51-52; Köymen, M. A., Tuğrul Bey ve Zamanı, İstanbul 1976, s.27.

${ }^{5}$ Bk. Sıbt, aymı eser, s.81 ve 96 . Ancak bu tercümede bir çelişki görülmekte, Ebû Sa'id'in ōnce Yûsuf'un başını kestirmek suretiyle öldürttüğü, sonra Yûsuf'un hapishanede hayaumı kaybettiği zikredilmektedir. Ebû Sa'id'in Yûsuf'un başım kestirdiği bir zuhul eseri Türkçe'ye aktarılmıș olmalıdır. Olaylar için bk. Köymen, M. A., Büyük Selçuklı Imparatorluğu Tarihi Alp Arslan ve Zamam, III, Ankara 1992, s.229. 
almamış ve sonuçta sultanlığı ele geçirmişti. Ancak bu olay Alp Arslan nezdinde Amîd el-Mülk'ün gözden düşmesine, belki de sultanın içten içe ona kin beslemesine sebep olmuştu. Nihayet bir içki meclisinde vezirin, sultanın bir Türkmen hakkında verdiği ölüm emrini önlemeğe çalışması Alp Arslan'ın Amîd el-Mülk hakkındaki düşüncelerini açığa vurmasına sebep oldu. Buna mukabil Amîd el-Mülk sultanın güvenini yeniden kazanmak için çareler aramağa başladı. Onun bu konuda başvuruda bulunduğu ilk kişi, vezirlik görevine tayin edilen Nizâm el-Mülk idi ve kutlayıp armağan olarak beş yüz ${ }^{6}$ altun takdim etti. Bu onun kurtulmak için harcadığı ilk rüşvet idi. Nitekim Nizâm el-Mülk, "kalbini hoş tutacağı" hususunda ona söz verdi. Ancak bu bir fayda sağlamamış olmalı ki, Amîd el-Mülk daha sonra Nişabur'da buluna Alp Arslan'ın Ümmi Kıpçak adlı hâtunu ve çocuğunun yanına gitti, "kendisinin affi hususunda sultana mektup yazmasını diledi ve ona beş yüz altun ve bir at hediye etti. Hâtun Amîd el-Mülk'ü affetmesi hususunda eşi sultana bir mektup gönderdi ise de, bu rüşvetin de faydası olmamış, belki de Alp Arslan'ın daha da kızmasına yol açmıştı. Nitekim sultan onun öldürülmesi için Merv el-Rûd'daki görevli Abdürrezzak b. Ebî Ali'ye bir haber gönderdi. Amîd el-Mülk bu durumu öğrendiğinde Nişabur reisi Mahmûd b. Ali'yi affı için aracı olması ve sultana bir mektup göndermesi hususunda ikna etti. Ayrıca Amîd el-Mülk, "sultana pek çok paralar vereceğini, affı konusunda yalvarıp yakarmayı" içeren bir mektup yazmıştı. Mahmud b. Ali her iki mektubu da sultana yolladı. Amîd el-Mülk ise sultanın kendisini öldürmekle görevlendirdiği gulama da para vermiş ve bir cevap gelene dek beklemesini sağlamıştı. Sonuçta Alp Arslan onun kesin olarak öldürülmesini istemiş ve bu emir yerine getirilmişti?

Görüldüğü üzere Amîd el-Mülk hayatını kurtarmak için sultana dahi rüşvet teklif etmiş, hâtununa, Nizâm el-Mülk ve daha alt tabakadaki gulama da rüşvet vermişse de, başarılı olamamış ve sonunda öldürülmüştü (1064). Onun ölümünün gerçek sebebi Nizâm el-Mülk'ün tahriklerinden ziyade ${ }^{8}$,

${ }^{6}$ Arapça metinde (Sevim, A., "Sıbt İbnü'l-Cevzî'nin Mir'âtü'z-Zaman Fì Tarihi'l- Âyan (Kayıp Uyunü't-Tevârih'ten Naklen Selçuklularla İlgili Bölümler”, Belgeler, Sayı: 18, Ankara 1992, s.141) beş yüz dinar olarak geçmektedir. Ancak Türkçe tercümede (Sevim, A., "Sıbt İbnü'l-Cevzî'nin Mir'âtü'z-Zaman Fî Tarihi'l- Âyan Adlı Eserindeki Selçuklular ile İlgili Bilgiler II, Sultan Alp Arslan Dönemi", Belgeler, Sayı:23, Ankara 1999, s.17) herhalde bir baskı hatası sonucu beş bin dinar şeklinde zikredilmiştir.

${ }^{7}$ Bk. Sıbt, Belgeler, Sayı: 23, s.16-20; Köymen, Alp Arslan ve Zamanu, III, s.165-172.

${ }^{8}$ Bk. Bundarî (Histoire Des Seldoucides De L'Irâq par al-Bondârî D'apre's Imad ad-Dîn alKatib al-Isfahânî, Texte Arabe nşr. M.T.Houtsma, Liede 1889, s.29/Trk.trc. Burslan, K., Irak ve 
Tuğrul Bey'in ölümünden sonra Amîd el-Mülk'ün Alp Arslan'a karşı davranıșı ve Tuğrul Bey dönemindeki gibi sultana ait bazı yetkileri kullanmak istemesi olmuştu. Nitekim daha sonra Nizâm el-Mülk'ün de sultana ait yetkileri paylaşmak istemesinden dolayı Melikşâh ile arası açılmıştı.

Galiba sultanın her hangi bir olay nedeniyle kızdığı șahısların canlarımı kurtarabilmek açısından başvurdukları son çare belki de rüşvet idi. Bu şahıslardan biri de Emîr Hezaresb idi. Alp Arslan Hârezm'de iken kendisine birçok değerli armağanlar ve paralar takdim edilmişti. Sultan bunlardan bir kese altunı büyük oğlu Ayaz'a uzatmış o da dizleri üzerinde süratle babasının yanına gidip uzatılan keseyi alarak aymı şekilde geri dönmüștü. Buna mukabil sultan Emîr Hezaresb'e de bir avuç altun uzattı. Ancak Hezaresb ayağa kalkarak sultana doğru yürüdü ve altunları alarak geri döndü. Bu olay sultanın son derecede ağrına gitmiş ve hürmette kusur ettiği için Hezaresb'i hâkimiyet sevdasıyla itham etmişti. Daha sonra Alp Arslan'ın Hacib Aytekin'i kılıcıyla ikiye bölüp Hezaresb'e göndermesi, onun korku ve endişeye kapılmasına sebep oldu. Hezaresb bu durumda Vezir Nizâm el-Mülk'e başvurmuş ona ve sultanm eşine paralar vermişti. Bu rüşvetler fayda sağlamış olmalı ki, Nizâm el-Mülk onu sultanın huzuruna götürdü. Sonuçta Alp Arslan onu affetmiş ve serbest bırakıp yönettiği ülkeye Huzistan'a geri göndermişti (Rebi II. 458/Mart 1066) ${ }^{9}$.

Nasr el-Devle Ahmed'in 1061'de ölümünden sonra, Sultan Alp Arslan döneminde Diyarbekir bölgesini yöneten Mervanî ailesinden iki kardeș arasında anlaşmazlık vardı. Bunlardan Ebu'l-Hasan Sa'id b. Mervan Diyarbekir'i, kardeşi Nizâm el-Dîn Nasr da Meyyâfarıkîn (Silvan)'i yönetmekte idiler. Ancak Nizâm el-Dîn Nasr bütün emîrliğe sahip olmak istiyordu. Nitekim o yönetimi ele geçirmek için önce Vezir Nizâm el-Mülk'e pek çok mücevher, para ve değerli armağanlar verdi. Bu rüşvet onun Nizâm el-Mülk ile sultanın huzuruna çıkmasını sağladı. Nizâm el-Dîn sultana da pek çok (göz doldurucu) para ve hediyeler sundu. Ancak Alp Arslan onlara daha önce Sa'id'i hükümdar yapacağı konusunda ant içtiğini söyledi. Selçuklu veziri, "onu (bu sorunu ) bana bırak” demiş ve Alp Arslan ava çıktuğında Sa'id'i getirtmiş ve

Horasan Selçukluları Tarihi, İstanbul 1943, s.28), Nizâm el-Mülk'ün Amid el-Mülk'ün bağımsız hareket etmesini kıskandığımı, onu tutuklatmak hususunda çareler düşündüğünü zikrediyor. Amîd el-Mülk de muhtemelen bu durumu sezmiş, yukarıda belirttiğimiz üzere Nizâm el-Mülk'ü ziyaret ederek ona beş yüz alun bırakmışu. Ancak daha sonra Nizâm el-Mülk sultamı tahrik etmiști.

${ }^{9}$ Bk. Sıbt, Belgeler, Sayı: 23, s.21-22; Kōymen, aynı eser, s.61-62, 73, 118, 123. 
zincire vurdurup zindana aturmışt. Avdan dönen Alp Arslan, Nizâm el-Dîn Nasr'a saltanat hil'atleri verdi ve onu Meyyâfarin'e göndererek Mervanoğullan tahtuna oturttu ${ }^{10}(\mathrm{~h} .463 / 1070-1071)$.

Tuğrul Bey'in ölümünün yarattğı kargaşadan yararlanarak isyan edenlerden biri Saganiyan (Çağaniyan) Emîri Musa bir kaleye sığındı ise de Selçuklu askerleri kısa zamanda burayı zorla ele geçirdiler. Sultan esir alınan Musa'nın öldürülmesini emretti. Musa canını kurtarabilmek için, rüşvet olarak, pek çok mal vermeği vaat etti ise de bu bir fayda sağlamadı. Alp Arslan bu rüşveti "şimdi ticaret zamanı değildir" diyerek güzel bir cevapla reddetti. Daha sonra emîrlerinden birini orada bırakarak Merv'e döndü ${ }^{11}$ (h.456/m.1064).

Sultan Alp Arslan'a rüşvet gönderenlerden biri de Horasan Amîdi olarak meşhur Muhammed b. Mansûr Nesevî idi. Ancak Nizâm el-Mülk daha sonra Harezm valiliğine atanan Muhammed b. Mansûr'u nedense kıskanıyordu (Acaba bu bölgenin valiliğini oğullarından biri için mi düşünmüştü ?). Nitekim Nizâm el-Mülk bir emîri beraberinde maiyeti ve hizmetkârları (hadem ve haşemi) ve onu borçlu gösteren senetler ile (vusulü divaniye) Muhammed'e gönderdi. Vezirin gayesi belki de onun sultan nezdindeki nüfuzunu kırmak ve küçük düşürmek idi. Ancak Muhammed b. Mansûr bu senetleri getiren ve hepsi de gulam olan maiyeti öldürtüp Ceyhun nehrine atturdı. $O$ bundan sonra yüz gulam satın aldı ve her birinin beline yüz dinar bağlayarak Alp Arslan'a hediye etti (rüşvet). Muhammed ayrıca sultana bir mektup yazarak, “... gönderilen gulamlar divanın hukukunu ihlal ettiler, ben de onun için bana kuşattuğın kılıç ile onların cezasını verdim..." dedi. Böylece Muhammed b. Mansûr, Nizâm el-Mülk'den daha

${ }^{10}$ Bk. İbn Al-Azraq Al-Fârıqî, Târîkh Al-Fìrıqî, nşr. B.A.L.Awad, Beyrut 1974, s.186- 188, Sıbt, Belgeler, Sayı: 23, s.47, Köymen, aym eser, s.161. Öte yandan bir başka rivayete göre Nizâm el-Dîn Nasr'ın Alp Arslan'a takdim ettiği rüşvet (hediye) yüz bin dinar idi. Sultan da onu huzuruna kabul ederek isteklerini yerine getirmişti. Ancak Alp Arslan onun bu parayı halktan gayr-i meşrû bir şekilde topladığını öğrendiğinde paranın aynen sahiplerine iadesi için Nasr'a geri vermişti. Bk. Bundarî, s.37/Trk. trc., s.36; Șeşen, R., "İmâd Al-Dîn Al-Kâtib Al-Isfahânî'nin Eserlerindeki Anadolu Tarihiyle İlgili Bahisler", SAD, III, Ankara 1971, s.252. Ancak Ahmed b. Mahmûd'a göre (Selçuk-Nâme, Haz. E. Merçil, İstanbul 1977, I, s.82), Nasr b. Mervan o yüz bin dinarn haslarından ve hazinesinden sultanın hizmetine ulaşurmışt.

${ }^{11}$ Bk. İbn el-Esîr, X, s.34/Trk.trc.X, s.47; Müneccimbaşı Ahmed b. Lütfullah,

Camiü'Düvel, Selçuklular Tarihi, I, Horasan-Irak, Kirman ve Suriye Selçuklulan, Yay., A. Öngül, İzmir 2000, I, s.33-34. 
akıllı davranmış ve rüşvet ile durumu kurtararak sultan tarafından mazereti kabul edilmiștit ${ }^{12}$.

Sultan Alp Arslan'ın kardeși Melik Kavurd ile birleşerek isyan edenlerden biri de Fars hâkimi Fazlûye olmuştu. Selçuklu sultanı bu durumu öğrendiği zaman 1 Muharrem 461/31 Ekim 1068'de önce Fazlûye üzerine yürümek maksadıyla Isfahan'dan ayrıldı. O Şiraz'a ulaștı̆ğında Fazluye'nin Hurşeh adında çok müstahkem bir kaleye sığındığı anlaşıldı. Alp Arslan bu durumda Fazluye ile uğraşmak görevini Nizâm el-Mülk'e bırakarak kendisi Kirman'a gitti. Sonuçta Selçuklu askerleri Fazluye'yi yakalayarak Nizâm elMülk'ün yanına getirdiler. Vezir kendisine çok para vereceğini bildiren Fazluye'yi ümitlendirdi ve "sultanla onun hakkında konuşacağı" vaadinde bulundu. Nitekim Fazlûye kendisini kurtarabilmek için Nizâm el-Mülk'e beş yüz bin (altun) dinar verdi ${ }^{13}$.

Nizâm el-Mülk Fazlûye'yi bu sırada Kirman'da Berdesir'i kuşatmakta olan Alp Arslan'ın huzuruna götürdü. Sultan yaptığı konuşmadan sonra belki de Nizâm el-Mülk'ün de etkisiyle, Fazlûye'yi affetti. Ancak bu sırada sultanın onunla konuşması da kanaatimce rüşvet içeren sözler ihtiva etmektedir, "İşlediğin suçlara rağmen seni affettim. Senin şu duruma gelmen, yani serbest bırakıp hizmetime almam nedeniyle sarf ettiğim parayı ver". Nitekim Fazlûye de canını kurtarmak için sultana para vermeği üstlenmiş, fakat serbest bırakılmayarak Istahr Kalesi'nde hapsedilmiști'4.

Öte yandan Sultan Alp Arslan ve kardeşi Melik Kavurd ile ilgili iki rüşvet rivayeti vardır. Bunlardan birincisine göre, Sultan Alp Arslan Malazgirt zaferinden sonra (26 Ağustos 1071) Hemedan'dan Isfahan'a yöneldi ve iki gün geçmeden kardeşi Melik Kavurd'un hâkimiyetindeki Kirman'a ilerledi. Sultan Berdesir civarında iken Melik Kavurd'un elçisi gelerek Alp Arslan'a tâbi olduğunu bildirdi. Ayrıca Kavurd kardeşine hediyeler de göndermiști. Muhtemelen o sultanın hareketini önlemek ve Kirman'da hâkimiyetini sürdürmek istiyordu. Alp Arslan kardeşinin özrünü kabul etmiş Kirman'ı ye-

12 Sadr'uddîn Abu'l-Hasan 'Ali İbn Nâsır İbn 'Ali al-Husaini, Ahbâr'üd-Davlat is.Saljuquyya, nşr. Muhammed Iqbal, Lahor 1933, s.33/Türkçe trc. N. Lügal, Ahbâr üd-Devlet isSelçukiyye, Ankara 1943, s.22-23; Köymen, aynı eser, s.142, 172, 250.

${ }^{13}$ Bk. A. Taneri ("Büyük Selçuklu İmparatorluğunda Vezirlik", TAD, Sayı: 8- 9, Ankara 1970, s.169) bu rüşveti elli bin dinar olarak kaydediyor.

${ }^{14}$ Bk. Sıbt, Belgeler, Sayı: 23, s.29-31; Ahbâr, s.42-43/Trk. trc. s.29-30; Köymen, ayn eser, s.47, 63- 64, İbn el-Esîr (X, s.71- 72/Trk. trc. X, s.76-77) olayları zikrediyorsa da rüşvet konusunda bir bilgi vermiyor. 
niden Kavurd'a bıraktığını, hediyeye de ihtiyacı olmadığını belirterek geri dönmüşsü. Böylece sultan kardeşinin teklif ettiği hediyeyi kabul etmemiş, yine de onu yerinde bırakmıștı. Ancak sadece Mîrhond ${ }^{15}$ ' da tespit edebildiğimiz bu rivayetin doğruluğu kronolojiye uymadı̆̆ı ve başka kaynakta yer almadığı için şüphelidir.

Bu iki kardeş arasında zaman-zaman meydana gelen anlaşmazlıklarla ilgili bir rivayet de Sıbt ${ }^{16}$ 'da görülmektedir. Buna göre Melik Kavurd Halife Kaim bi-Emrillâh'a sultanla arasındaki sorunları çözme hususunda yardımcı olması hususunda üç yüz bin altun göndermişti. Yine başka bir kaynakta tespit edemediğimiz bu rivayet Melikşâh dönemi olayları içinde zikrediliyor. Ancak sultanın ismi verilmiyor. Kavurd, kardeşinin ölümünü (1072) duyar duymaz Melikşâh'a karşı harekete geçtiğine göre, bu rüşvet olayı daha çok isyanların görüldüğü Alp Arslan dönemiyle ilgili olmalıdır.

Selçuklu döneminde rüşvet ile iş görmek isteyenlerden biri de, daha önce zikri geçen, Huzistan ve Basra çevresini yöneten Emîr Hezaresb idi. O Tuğrul Bey'in ölümünden sonra (1066), meydana gelen kargaşa ortammnda Halife Kaim bi-Emrillâh'a gönderdiği elçi vasıtasıyla kendisine "melik unvanı" tevcih edildiği takdirde yüz bin dinar vereceğini iletmiști. Ancak halife rüşveti kabul etmeyerek verdiği cevapta, unvan işinin Selçuklu hanedanı hakkında mümkün olduğunu, bu bakımdan böyle bir meselenin söz konusu olamayacağını bildirmişti ${ }^{17}$.

\section{Sultan Melikşâh Dönemi}

Sultan Alp Arslan'ın ölümünden sonra genç yaşta tahta oturan Melikşâh'a karşı çıkanlardan birisi de amcası Melik Kavurd idi. Kavurd, Melikşâh ile saltanat mücadelesine girişebilmek için Rey ve Hemedan arasındaki yörelerde bulunan Türkmenler'den yardım almak istiyordu. Onun bu girişim ve faaliyetini haber alan Sultan Melikşâh ve Vezir Nizâm elMülk Rey kalesinde bulunan beș yüz bin dinar (altın), beş bin giysi ve silâhları alarak Kavurd'dan önce Türkmenlere gittiler ve söz konusu para ile giysileri onlara dağıttılar. Böylece bir ölçüde rüşvet ile onları kendi taraflarına çekmeği başardılar. Bu durum Melik Kavurd'un Melikşâh karşısında

${ }^{15}$ Bk. Mîrhond, Tarih Ravzat el-Safâ, Tahran hş. 1339, IV, s.271.

${ }^{16} \mathrm{Bk}$. Sevim, A., “Sıbt İbnü'l-Cevzî'nin Mir'atü'z-Zaman Fi Tarihi'l-Âyan Adlı Eserindeki Selçuklular ile ilgili Bilgiler, III, Sultan Melikşâh Dönemi”, Belgeler, Sayı: 24, Ankara 1999, s.15.

${ }^{17}$ Bk. Köymen, aynı eser, s.76; Merçil, E., Kirman Selçukluları, Ankara 1989, s.22. 
mağlubiyetine sebep oldu (Nisan 1073) ${ }^{18}$. Rüșvet bir hükümdarın yerini sağlamlaşturırken, bir diğerinin mücadeleyi kaybetmesine yol açıyordu.

Nizâm el-Mülk'ü kıskananlar zaman-zaman Melikşâh'a şikâyette bulunarak onunla Selçuklu sultanının arasını açmağa çalışmakta idiler. Bu şahıslardan biri de Divan-ı İnşâ Sahibi (Divan-ı Resâil) Kemâl el-Mülk'ün oğlu Seyyid el-rüesâ Ebu'l-Mehasın idi. Ebu'l- Mehasın divanda babasının naibi olup, aynı zamanda Nizâm el-Mülk'ün damadı ve Melikşâh'ın da nedimi idi. Belki de o statüsünden yararlanarak sultana, "Nizâm el-Mülk ile adamlarını bana teslim et, ben de onlardan alıp bir milyon dinar ${ }^{19}$ vereyim. Çünkü onlar, "hazine ve halkın malını yiyorlar, bazı şehir ve köyleri kendilerine tahsis ediyorlar" dedi. Bu olayı duyan Nizâm el-Mülk hemen karșı harekete geçti, gulamlarının da katıldığı büyük bir ziyafet tertipledi. Bu ziyafete Melikşâh geldiği zaman Nizâm el-Mülk, "Ben sana, babana ve dedene hizmet ettim. Benim hizmet hakkım vardır. Bana ulaşan haberlere göre malının onda birini aldığım söyleniyor. Malını aldığım doğrudur” diyerek bu malları sultan için harcadığını, yoksa bu paraları hazinesinden vermesi gerektiğini ifade etmişi. Burada $\mathrm{S} ı b t^{20}{ }^{\prime}$ ın rivayeti doğru ise, Nizâm el-Mülk sultanın gözünü doyuracak kadar mücevher, para ve mallar yani rüşvet takdim edip "Hep bunlar sultanındır ve onun için hazinede saklanmıșur" diyerek ayrıca kendisi hakkında dedikodu yapanlardan da pek çok para alacağı hususunda ona güvence verdi. Melikşâh, belki de bu rüşvetin veya onun hissî konuşmasının etkisiyle Ebu'l-Mehasın ve öteki ilgili kimseleri yakalaup ve gözlerine mil çektirerek Save Kalesi'nde hapsettirdi' ${ }^{21}$.

Kemâl el-Mülk bu olayı duyduğu zaman Nizâm el-Mülk'ün evine sığındı ve iki yüz bin dinar rüssvet vererek ölümden kurtulabildi. O Divan-1 tuğra ve inşa'dan da azledildi, yerine Müeyyid el-Mülk b. Nizâm el-Mülk tayin edildi.

${ }^{18}$ Bk. Sıbt, Belgeler, Sayı: 24, s.2; Merçil, aynı eser, s.29. Ōte yandan savaştan sonra Melikşâh'ın askerleri Nizâm el-Mülk'e başvurarak kazandıklan büyük zafere karşıııtık, iktâ ve maaşlarının fazlalaştırılmasını istemişler, bu yapılmadığı takdirde Kavurd'u tahta çıkaracaklarımı îma etmişlerdi. Selçuklu askerleri kazandıkları galibiyet karșlığında bir ölçüde rüşvet isteyerek Melikşâh'ı tehdit etmişlerdi. Ancak bu rüşvet isteği Kavurd'un ölümüne sebep olmuştu, bk. Merçil, aynı eser, s.35.

${ }^{19} \mathrm{Bk}$. Taneri ("Vezirlik", s.139)'ye gòre, yüz bin dinar teklif etmişti.

${ }^{20}$ Bk. Belgeler, Sayn: 24, s.56.

${ }^{21}$ Sıbt'a göre (aymı yer), Ebu'l-Mehasın ònce Save'ye gõnderilmiş, sonra iki gōzü bıçakla oyularak sultanın önūndeki av kōpeklerine yedirilmişti. 
Bir diğer rivayete göre ${ }^{22}$, oğlunun gözden düșmesiyle Kemâl el-Mülk (Devle) de itibarını kaybetti, malından sultan hazinesine üç yüz bin altun vermeğe mecbur edildi (476 Şevval/Şubat 1084). Görüldüğü gibi bu olayda hem Melikşâh hem de Nizâm el-Mülk rüşvet almışlardır.

Selçuklu ordusu Mervanî Emîrliği'ne son vermek üzere faaliyette iken Mervânoğlu Nasr el-Devle Mansûr buna engel olmağa çalıștı. Melikşâh kardeşi Tekiş'in isyanıla meşgul olduğu sırada, Mansûr Selçuklu sultanının karargâhına kadar gelerek değersiz bir at ve altun eşyalar getirip, rüşvet olarak, bunları Melikşâh'a ait çadırlara koydu, fakat hiç kimse merak edip bunlara bakmadı. O daha sonra sultanın hâtununa (Terken Hâtun) çok az armağanlar getirdi. Fakat bunların makbule geçmediği ve bir fayda sağlamadığını gören Mansûr aradan beş gün geçmeden Ayaz el-Nizamî'den bin altın borç almış, hattâ aracılık yapan İranlı bir kadına borç para bulmasını emretmişti. Ancak Melikşâh faizle borç alınmasını yasakladığı için hiç kimse ona borç vermemişti. Bu arada Fahr el-Devle İbn Cüheyr'den Diyarbekir bölgesinde dört kalenin (Siirt, Erzen, Bitlis ve Ahlat) ele geçirilmiş olduğu, Silvan halkının da şehri teslim edeceği hususunda bir mektup geldi. Buna mukabil Mansûr Silvan'ı muhafaza etmek arzusundan vazgeçmemiş, son olarak Melikşâh'ın kızlarından biriyle evlenme karşıllğında, altınış bin altun çeyiz vereceğini ileri sürmüştü. Bunun üzerine ona, "Sen faizle borç arıyorsun, senin altının nereden olacak" denildi. Böylece Mansûr rüşvet yoluyla ülkesine sahip olmak istedi ise de, zaten parası da olmadığından, bir sonuç elde edememişti $(1085)^{23}$.

Diyarbekir bölgesinin fethi sırasında bir rüşvet olayı daha zikrediliyor. Meyyâfarıkîn (Silvan)'ı kuşatan Selçuklu ordusunu yöneten Hacip Altuntak, Meyyâfarıkînliler'den rüşvet almakta bu nedenle şehrin kuşatmasını özellikle uzatmakta idi. Onun anî ölümüyle geride bıraktığı şeyler (tereke) arasında halktan gelen mektuplar bulundu, böylece onun Silvanlılar'dan rüşvet aldığı açıkça ortaya çıktı $(1084)^{24}$.

${ }^{22}$ Fazla bilgi için bk. Bundarî, s.60/Trk.trc.s.61. Ibn el-Esir, X, s.131/Trk. trc. X, s.123; Sıbt, aynı eser, s.56; Ahmed b. Mahmûd . Selçuk-Nâme, I, s.142-144; Müneccimbaşı, Trk. trc. I, s.55; Kafesoğlu, I., Sultan Melikşâh Devrinde Büyük Selçuklu Imparatorluğu, İstanbul 1953. s.198.

${ }^{23}$ Sıbt, Belgeler, Sayı: 24, s.63-64; Yınanç, Türkiye Tarihi, s.147; Kafesoğlu, aynı eser, s.53.

${ }^{2.1} \mathrm{Bk}$. Sıbt, aymı eser, s.66; Yınanç, aynı eser, s.149; Mumcu, aymı eser, s.76. 
Selçuklu ordusunun Diyarbekir bölgesini fethi sırasında bir başka rüşvet olayı daha görülmektedir. Selçuklu ordusu bu bölgeye geldiğinde (1084 baharı), Mervanî Emîri Nasr el-Devle Mansûr Musul Emîri Şeref el-Devle Müslim b. Kureyş'i yardıma çağırmıştu. Ancak Selçuklu ordusunda yer alan Artuk Bey idaresindeki Türkmenler bu birleşik Arap askerlerinden iki kat fazla idi. Diyarbekir önünde bulunan Müslim b. Kureyş bu durumda Mansûr ile beraber şehre sığınmaktan başka çare bulamamıșt. Daha sonra gelişen olaylar karşısında Müslim, şehirden çıkabilmek için Artuk Bey'e, "Arzu ettiği miktarda para vereceğini" bildirdi. Artuk Bey de olumlu bir cevap gönderdi. $\mathrm{O}$ zaten Selçuklu ordusunu yöneten İbn Cüheyr ile anlaşamıyordu. Bu bakımdan Türkmenler'in büyük bölümüyle Diyarbekir önünden ayrıldı. Böylece Selçuklu kuvvetlerinin büyük bir kısmının çekilmesiyle Müslim Diyarbekir'den ayrılarak (29 Temmuz 1085) Rakka'ya gitti ve söz verdiği paradan daha fazlasım Artuk Bey'e gönderdi. Müslim b. Kureyş verdiği rüşvet ile kendisini tehlikeli bir durumdan kurtarabilmişti ${ }^{25}$.

Sultan Melikşâh döneminde bir rüşvet isteme olayı Suriye fatihi Atsız tarafından gerçekleştirilmiştir. Atsız, Mirdasoğulları emîrliğine ait Rafaniyye'yi aldıktan sonra buranın hâkimi Halep Emîri Nasr b. Mahmud'a haber gönderip, "Babası Emîr Mahmud'un bıraktığı paralardan bir kısmını kendisine göndermesini, ayrıca kız kardeşiyle de evlenmek istediğini ve nihayet Haleb'in kendisine teslimini" bildirmişti. Ancak Nasr ona on beş bin altun rüşvet vermiş, Atsız'ın da buna razı olmasıyla ikisi arasındaki sorun çözülmüş̧ü ${ }^{2 i}(468 / 107-1076)$.

Süleyman Şâh'ın ölümünden (1086) sonra bir süre Türkiye Selçuklu Devleti'ni onun vekili Ebul-Kasım yönetmiş ve Sultan Melikşâh'a tam olarak itaat etmeyerek Bizans ile de işbirliği yapmıştu. Sultan Melikşâh bu durumda önce Emîr Porsuk ardından da Bozan'ı Anadolu'ya gönderdi. Bozan'ın gelmesiyle durumun nezaketini anlayan Ebu'l-Kasım Anadolu'yu yönetebilmek için izin almak maksadıyla beraberinde altın yüklü on beş katır ile Selçuklu sultanının yanına gitti. $\mathrm{O}$ bu rüşvet ile (hoping that bribe...) gayesine ulaşabileceğini ve Emîr Bozan'ı geri çektirebileceğini ümit ediyordu. Ebu'l-

${ }^{25}$ Bk. Sıbt, aymı eser, s.58-59; Kafesoğlu, aymı eser, s.51. Yınanç'a göre (s.141). Artuk Bey Müslim'e haber göndererek muayyen mal ve para karșlığında kuşatmadan vazgeçeceğini bildirmişti.

${ }^{26}$ Bk. Sıbt, aynı eser, s.15; Sevim, A., Suriye ve Filistin Selçukluları Tarihi, Ankara 1983. s. 70 . 
Kasım sultanı Isfahan yakınında buldu ise de şahsî görüş̧me talebi reddedildi, gönderdiği aracıların da bir faydası olmadı. Melikșâh, "Ben otoriteyi bir kere ve bütünüyle Emîr Bozan'a verdim. Onu oradan azletmeği istemiyorum... Ebu'l-Kasım bu parayı Bozan'a götürsün. Bozan neye karar verirse benim kararım olacaktır" dedi. Ebu'l-Kasım uzunca bir süre Isfahan'da bekledi ve ıztırab çekti ise de bir sonuç elde edemeden Bozan'ı bulmak için harekete geçti. Ancak yolda Bozan'ın adamlanı tarafından yakalandı ve yay kirişiyle boğduruldu. Böylece Ebu'l-Kasım'ın kendisini kurtarmak ve yerinde kalmak için teklif ettiği altun yüklü on beş katır rüşvet bir işe yaramamışı ${ }^{27}$.

Sultan Melikşâh zamanında vukû bulan bir olay da muhtemelen rüşvetle ilgilidir. Basra mültezimi çok zengin bir Yahudi İbn Allan ile Vezir Nizâm elMülk'ün arası çok iyi olup, onun ileri gelen adamları arasındaydı. Bu ikisinin arasının bu kadar iyi olmasının sebebi ne idi? Kanaatimce İbn Allan zamanzaman hediye yoluyla vezire rüşvet vermiş olmalıdır. Öte yandan Emîr Sa'd el-Devle Gevherâyin ve Humartegin el-Şarabî'nin Vezir Nizâm el-Mülk ile aralarında düşmanlık vardı. Bu ikisinin tahrikleriyle Sultan Melikşâh İbn Allan'ın öldürülmesine karar verdi. Ancak sultan önce ondan dört yüz bin dinar $^{28}$ aldı, sonra da yakalatup öldürttü (h.472/m.1079) ${ }^{29}$. Sultan Melikşâh bu dört yüz bin dinarı müsadere yoluyla mı yoksa İbn Allan'ın canını bağışlamak için mi aldı? Kaynaklarda fazla bir bilgi bulunmadığı için bu durumu tespit etmek mümkün görünmemektedir.

Nizâm el-Mülk'ün bu olaydan sonra canı sıkılmış ve üç gün evinden dışarı çıkmamıştı. Ancak daha sonra ortaya iki rivayet çıkıyor. İbn elEsîr'inkine göre ${ }^{30}$, Nizâm el-Mülk sultan için büyük bir ziyafet hazırlayıp burada Melikşâh'a pek çok hediyeler sundu. Sultan vezirini üç gün huzuruna çıkmamasından dolayı kınadı. Nizâm el-Mülk de özür diledi. Nizâm elMülk'ün bu ziyafette sunduğu hediyeler belki de sultana karşı davranışından dolayı özür dileme açısından bir rüşvet kabul edilebilir mi?. Sıbt'a göre ${ }^{31}$, Nizâm el-Mülk İbn Allan için düzenlenen ve birçok kimsenin katıldığı dua

27 Bk. The Alexiad of Anna Comnena, Translated from the Grek by E.R.A. Sewteer. Penguin Boks, Bungay, Suffolk 1969, s.207; Kafesoğlu, aynı eser, s.105- 106; Turan, O.. Selçuklular Zamanında Türkiye, İstanbul 1971, s.87.

${ }^{28}$ Sıbt (Belgeler, Sayı: 24, s.36) ve Ahmed b. Mahmud'a göre (Selçuk-Nâme, I, s.137), dört yüz bin dinar idi. Ancak İbn el-Esir (X, s.116/Trk. tuc. X, s.111) yüz bin dinar olarak zikrediyor.

${ }^{2 .)} \mathrm{Bk}$. Sıbt, aynı yer.; İbn el-Esir, aynı yer.

${ }^{30} \mathrm{Bk}$. İbn el-Esir, aynı yer.

${ }^{31}$ Bk. Belgeler, Sayı: 24, s.37. 
törenine Isfahan'a dönmüş olan sultanı da davet etti ve onu İbn Allan'ı öldürttüğü için ayıplayıp kınadı. Melikşâh da istemeyerek de olsa ona, gönlünü alan bir cevap verdi.

Bir rivayete göre ${ }^{32}$, "Sultan Melikşâh bir ihtiyaç için iki haftada iki yüz bin dirhem tedarik etmesini emrederek Nizâm el-Mülk'ü Isfahan'a yollamıștı. Nizâm el-Mülk bu yolculuğu sırasında bir köy ağasının (dihkan) evinde misafir oldu. Bu dihkan Nizâm el-Mülk'ün yolculuğunun gayesini öğrendiğinde, az-çok okuma-yazma öğrenmiş olan oğlunun devlet hizmetine kabul edildiği takdirde der hal parayı verebileceğini söyledi. Bu tekliften memnun olan vezir, derhal olayı sultana bildirdi. Fakat ananeye muhalif olan bu rüşvet teklifi Melikşâh'ı fevkalade sinirlendirmiş. Dihkanın malına ihtiyacı olmadığını, onun ehliyetsiz çocuğunu Müslümanlar üzerine tayin ettiğinde o lâyı olmayan ve beğenilmeyen işler yaptı̆gnda Melikşâh rüşvet aldı diye ayıplarlar demiş ve Nizâm el-Mülk'e de kızarak ona mezun olduğu işi yerine getirmesini yazmışt. Çünkü avam ve köylü çocuklarının biraz okuyup yazma ögrenerek memuriyet sınıfına girmeleri ananeye uymamakta idi.

Selçuklu Devleti'nin ileri gelen ve başarılı devlet adamlarından biri de Müstevfî Şeref el-Mülk Ebû Sa'd Muhammed b. Mansûr el-Harezmî (öl.494/1100- 1101) idi. O Sultan Alp Arsan ve Melikşâh dönemlerinde görev almıs ve önemli imar faaliyetlerinde bulunmuştu ${ }^{33}$. Şeref el-Mülk'ün katlinden ve Melikşâh'ın ölümünden bir süre önce divandan ayrılmak istemiş ve sultana yüz bin dinar (rüşvet) takdimle istifası kabul edilmişti ${ }^{34}$.

Melik Tutuş beraberinde Aksungur, Bozan ve Yağısıyan gibi emîrler bulunduğu hâlde Celâl el-Mülk b. Ammâr'ın yönetimindeki Trablus-şam'ı kuşatu (1091 yılı sonları). Celâl el-Mülk ise Tutuş'un ordusunun şehir önünden ancak hile yoluyla uzaklaşturılabileceğini anlamıșt. Bu bakımdan Tutuş'un yanındaki emîrlere haber gönderip, onu bu ișten vazgeçirmeğe teşvik etmelerini istedi. Fakat emîrlerden bu konuda bir istek görmedi. Öte yandan Kasım el-Devle Aksungur'un yanında Zerrîn Kemer adlı bir veziri

${ }^{32}$ The Tadhkuratu 'Sh-Shu'ara ("Memoirs of The Poets") of Dawlat Shâh Bin 'Alâ u'dDawla Bakhtishâh Al-Gazî of Samarqand, nşr. E.G. Browne, London 1901, s.180-181.Krş. Köprülü, M.F., Bizans Müesseselerinin Osmanlı Müesseselerine Tesiri, İstanbul 1981, s.169.

${ }^{33}$ Bk. Bundarî, Trk.trc., s.31-32, 60-61 ,64; Ahbâr, s.69/Trk. trc.s.47; İbn el-Esîr, X, 54 , 326/ Trk. trc. X, s. 63 ve 268.

${ }^{34}$ Bk. İbn el-Esîr, X, s.326/Trk.trc.X, s.268; Abbas İkbal; Vezâret der ahd-1 selâtin-i buzurg1 Selcukî, Tahran hş. 1338, s.54-55. 
vardı. İbn Ammâr ona elçi gönderip hediye ve para (rüşvet) vererek kuşatmanın kaldırılmasına yardımcı olmasını istedi. $O$ da efendisi Aksungur ile beraber Tutuş'un kuşatmaya son verip oradan ayrılması için gayret gösterdi. İbn Ammâr Aksungur'a otuz bin dinar para ile bir o kadar da hediye gönderdi. Ayrıca Sultan Melikşâh'ın Trablus-şam'ın idaresini kendisine bıraktığını bildiren menşurları gösterdi. Böylece Aksungur için bahane çıkmış oldu ve Tutuş'a, "Ben elinde böyle menşurlar bulunan biriyle savaşmam" dedi. Tutuş ona bu sözleri için çok kızdı ise de, bu bir fayda sağlamadı. Aksungur ertesi gün oradan ayrıldı. Bu durumda Tutuş da Trablus-şam'dan uzaklaşmak zorunda kaldı. Böylece İbn Ammâr rüşvetle kuşatmadan kurtulmuş oldu ${ }^{35}$.

\section{Sultan Berkyaruk Dönemi}

Sultan Melkşâh'ın ölümüyle (1092) başlayan taht mücadelesinde küçük yaştaki oğlu Mahmûd'u sultan yapmak maksadıyla harekete geçen Terken Hâtun'un bu gayesini gerçekleştirebilmek için başvurduğu çarelerden en önemlisi rüşvet idi. O önce Selçuklu emîr ve askerlerini kendi tarafına çekebilmek için devlet hazinesinden rüşvet olarak, Melikşâh'ın yanında bulunan, bir milyon dinar gibi büyük miktarda parayı dağıtmıșt ${ }^{36}$.

Öte yandan Nizâm el-Mülk taraftarları (Nizamiye) da Berkyaruk'u sultan ilân ettiler. Berkyaruk ve beraberindekilerin Rey yakınındaki Taberek kalesini ele geçirmeleri üzerine Terken Hatun askerlerine üç milyon dinar gibi büyük miktarda rüşvet dağıtarak harekete geçirdi. Ancak Bürücird'de 17 Ocak 1093'teki savaşı Berkyaruk kazandı. Savaşı kaybeden Terken Hâtun ve oğlu Mahmud Isfahan'a çekildiler. Berkyaruk bu şehirde onları uzun süre muhasara etti. Terken Hâtun bu kuşatmayı kırabilmek için askerlerine bol miktarda para dağıtmağa devam etti. Sonuçta iki taraf arasındaki antlaşmanın maddelerinden biri de kuşatmadan vazgeçmesi karşılığında Berkyaruk'a (babasının mirasından) beş yüz bin dinar verilecekti ${ }^{37}$. Terken

${ }^{35}$ Bk. İbn el-Esîr, X, s.202-203/Trk.trc., s.175- 176; Kafesoğlu, Melikşâh, s.100; Sevim, Suriye Selçukluları, s.135-136; Özaydın, A., Ammaroğulları mad., DiA.

${ }^{36}$ Bk. Bundarî, s.82/Trk.trc., s.84; Ahmed b. Mahmud, aym eser, II, s.30; Özaydın. A., Sultan Berkyaruk Devri Selçuklu Tarihi (485-498/1092-1104), İstanbul 2001, s.15 ve 170. Bir rivayete gỏre. Terken Hâtun oğlu Mahmud'a biat edilmesini sağlamak maksadıyla Halife Muktedî'ye yüzbin altun göndermişti, bk. Anadolu Selçuklulan Devleti Tarihi, III, Tıpkıbasım ve Türkçe trc., F. Nafiz Uzluk, Ankara 1952, s.18/Trk. trc., s.10.

${ }^{37}$ Bk. Ravendî, Muhammed b. Ali b. Süleyman, Rahat-Us-Sudür ve Âyet-Üs-Sûrûr, nșr. Muhammed İkbal, London 1921, s.141/Trk.trc., A.Ates, Ankara 1957-1960, I, s.138; Hamdullah 
Hâtun ise oğlunu tahta geçirebilmek hırsından bir türlü vazgeçmiyordu. O bu maksatla Azerbaycan hâkimi İsmail b. Alpsungur Yakutîye bir ittifak teklif etti. Terken Hâtun Berkyaruk'un bertaraf edilmesi karşılığında İsmail'e kanaatimce bașka türlü bir rüşvet teklifinde bulunuyor, bu isteği gerçekleștiğinde onunla evlenmeği vaat ediyordu. İsmail yeğeni Berkyaruk'a karşı olan bu teklifi kabul etti. Daha sonra Terken Hâtun İsmail adına hutbe okutup oğlu Mahmûd ile adına para bastırdı. Ancak Terken Hâtun'un bütün bu çabaları sonuç vermemiş, neticede olaylar Berkyaruk lehine gelişmiști ${ }^{38}$.

Bu dönemde rüșvet veren devlet adamlarından biri Vezir Tac el-Mülk Ebu'l-Ganaim idi. O taht mücadelesinin başlangıcında Terken Hâtun ile beraberdi. Bürücird Savaşı'ndan sonra Terken Hâtun'un yanından kaçan Tâc el-Mülk yakalanıp Isfahan'ı kuşatmakla meşgul olan Berkyaruk'un karargâhına götürüldü. Berkyaruk onun kabiliyetini bildiği için vezir tayin etmek istedi. Tâc el-Mülk bu durumda kendisine karșı olan Nizâm el- Mülk'ün önde gelen gulamlarının gönlünü almak için harekete geçerek onlara eşya ve mallardan başka iki yüz bin dinar rüşvet dağıttı. Başlangıçta bu rüşvet ișe yaradı ise de, daha sonra Nizâm el-Mülk'ün nâibi Osman gulamlanı tahrik

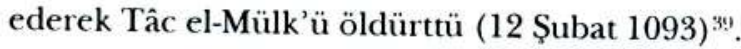

Sultan Berkyaruk Aralık 1094/Ocak 1095 tarihinde Müeyyid el-Mülk b. Nizâm el-Mülk'ü vezir tayin etmiști. Ancak Nizâm el-Mülk'ün bu kabiliyetli oğlunun vezirliği uzun sürmedi ${ }^{t 0}$. Berkyaruk'un annesi Zübeyde Hâtun ile devlet adamlarmdan Müstevfi Mecd el-Mülk sultanı Müeyyid el-Mülk aleyhinde kışkırttular. Bu ikisine vezirlikte gözü olan Nizâm el-Mülk'ün öteki oğlu Fahr el-Mülk de dâhildi"1. Berkyaruk sonuçta 1095 yılı içinde Müeyyid el-Mülk'ü görevinden azletti. Selçuklu sultam onun yerine kardeși Fahr el-

Müstevfî Kazvinî, Tarih-i Güzide, nşr. 'Abd el-Hüseyin Nevâî, Tahran hş. 1336-1339, s.440; Mirhond, IV, s.30; Özaydın, aym eser, s.19; Taneri'ye göre ("Vezirlik", s.169) bu miktar elli bin dinar idi.

${ }^{38}$ Bk. Ravendî, s.141-142/Trk. trc. I, s.138; Özaydın, aym eser, s.21-22.

${ }^{39}$ Bk. İbn el-Esîr, X, s.616/Trk. trc., X, s.185-186; Özaydın, aynı eser, s.20-21. Öte yandan Abbâs Ikbal'e göre (Vezâret der 'Ahd-ı Selâtin-i Buzurg-ı Selçukî, s.95) Tâc el-Mülk vezir olma karşılığında iki yüz bin dinar verecekti. Ancak vezirliğin Nizâm el-Mülk hanedanından başkasına gitmesini istemeyen Nizâm el-Mülk taraftarı (Nizâmiye) ayaklanarak Tâc el-Mülk'ü öldürdüler.

${ }^{10}$ Abbâs Ikbâl'e göre (aynı eser, s.127) iki aydan biraz fazla vezirlik yapmışt.

11 İbn el-Esir'e gòre (X, s.252/Trk. trc., X, s.212) iki kardeş arasında babaları Nizâm elMülk'ün miras olarak bıraktığı mücevherat dolayısıyla düşmanlık vardı. 
Mülk'ü atamıştı. Bu atamanın karşılığı verilen rüșveti şu şekilde sıralayabiliriz ${ }^{42}$, "Atlastan otağlar, Cehremî çadır, güzel silâhlar, kıymetli taşlar kakılmış eğer ve koşum takımları, kolanı bağlanımış Arap atlar, zagnos kuşları, silâh deposu gibi pek çok savaş malzemesi”.

Müeyyid el-Mülk daha sonra Muhammed Tapar'ın yanına gitmiş ve onu isyana teşvik etmişti. Sultan Berkyaruk ve kardeşi Muhammed Tapar arasındaki ikinci savaş 5 Nisan 1101 tarihinde gerçeklești. Bu savaş sırasında Muhammed Tapar mağlup oldu ve veziri Müeyyid el-Mülk esir düștü. Berkyaruk esir düşen Müeyyid el-Mülk'ün yüz bin dinar (alın) karşılığında vezir tayin edilme isteğini uygun gördü ve onun parayı verdiğinin ertesi günü vezirlik hokka takımının önüne konulacağı kararlaștırıldı. Ancak hazine görevlileri ile onun arasında paranın cinsinden dolayı anlaşmazlık çıkması ve bu konuda titizlenmesi nedeniyle ödeme ertesi güne kalmışı. Ertesi gün Berkyaruk öğle vaktinde çadırında dinlendiği sırada bir taşdarın Selçuklular aleyhindeki sözleri üzerine elinde kısa bir kılıçla otağından çıkmış ve Müeyyid el-Mülk'ü çağırtarak boynunu kesmişti ${ }^{43}$.

Sencer'in meliklik dönemindeki ilk veziri Kiya Mücir el-Devle Ebu'l-Feth Ali b. Huseyn Erdistanî idi. Sultan Berkyaruk Sencer'e Horasan'ı ikta olarak verdikten sonra adı geçeni vezir tayin etmişsi (n.490/m.1097). Ancak onun vezirliği uzun sürmemiş, Fahr el-Mülk b. Nizâm el-Mülk Sencer'in annesi (Tâc el-Dîn Seferiyye Hâtunn) "ve Emîr Erkuş (Bozkuş veya ümeraya) birçok mal rüşvet vererek (emvâl-i vâfir be-rüșvet dâd) vezirliği ele geçirmişsti ${ }^{15}$.

Melik Sencer'in Horasan'daki rakibi Emîr-i Dâd Habeşî b. Altuntak idi. Nitekim bu bölge için yapılan hâkimiyet mücadelesinde Berkyaruk da

42 Ravendî, Rahat-Üs-Sudûr ve Âyet-Üs-Sürûr, s.143/Trk. trc., I, s.140; İbn el-Esîr, X, s.252/Trk. trc., X, s.212; Abbâs ikbâl, aynı eser, s.204- 205; Özaydın, aym eser, s. 48, 56, 170, 197.

${ }^{13}$ Bk. Ravendi, s.17/Trk.trc., I, s.144; Muhammed b. Muhammed el-Huseyni el-Yezdi, elUraza Fi'l-Hikâyet el-Selcukiyye, nşr. Karl Süsseheim, Kahire h. 1326, s.80; Merçil, E.. "Selçuklular'da Taşdâr Müessesesi", Prof.Dr. İsmail Aka Armağam, İzmir 1999, s.57; Mumcu (Osmanlı Devleti'nde Rüşvet, s.76), Müeyyid el-Mülk'ün tekrar vezir olduğunu zikredip. muhtemelen paramın tam olarak ódenmesinden dolayı sultan tarafından öldürüldüğŭnü belirtiyorsa da, olay yukarıda açıkladığımız șekilde gerçekleșmiștir.

'A Sencer ve Muhammed Tapar'm annesi için bk. İbn el-Esîr, X, s.593/Trk, trc., X, s.469; Abbas Íkbal, Vezaret, s.118.

${ }^{45}$ Bk. Ibn el-Esir, X, s.265, 378/Trk. tuc.. X, s.221 ve 306; Nâsır el-Dîn Münşîy-i Kirmanî, Nesâim el-Eshar, nşr. Mîr Celâl el-Dîn Muhaddis, hş. 1338 Tahran, s.57; Abbas Íkbal, aym eser, s.194-195, 201, 209. 
Habeşî b. Altuntak'ı destekliyordu. İki taraf arasındaki savaşta Melik Sencer rakiplerini mağlup etti. Habeşî savaş sonrası kaçmağa muvaffak olduysa da bir grup Türkmen tarafindan yakalandı, o hayatının bağışlanması için Türkmenlere yüz bin dinar verdi. Fakat bu rüşvet bir fayda sağlanmadı ve Türkmenler onu Emîr Bozkuş'un huzuruna götürdüler. $\mathrm{O}$ da Habeşînin derhal öldürülmesini emretti ${ }^{46}(1100)$.

Öte yandan Melik Sencer'in en büyük emîri Bozkuş h.494/m.1101- 1101 yılında Batınîler üzerine sefer tertiplemiş ve onların hâkimiyetindeki Tabes'i kuşatmıştı. Selçuklu kuvvetleri bu şehri mancınıkla taş yağmuruna tutarak surların büyük kısmını tahrip etti. Tabes halkı güç durumda kaldı, Emîr Bozkuş kaleyi ele geçirmek üzere idi. Fakat Batunîler çok miktarda rüşvet gönderip kendilerinden istenilen şeylerden vazgeçmesini istediler. $\mathrm{O}$ da aldığı rüşvet nedeniyle kuşatmayı kaldırarak Tabes'den ayrıldı. Belki de bu sebeple daha sonra Batınîler Melik Sencer ve Emîr Bozkuş'u birbirine düşürmek için onlara mektuplar bıraktılar. Bu durumda Emîr Bozkuş Batınîler üzerine ikinci bir sefer tertipledi (h.497/m.1103- 1104) ${ }^{47}$.

\section{Sultan Muhammed Tapar Dönemi}

Sultan Muhammed Tapar Batınîlere karşı harekete geçerek onların önemli kalelerinden biri olan Şahdiz'i kuşatmıştu. Batınîler bu kuşatma sonucu çok zor durumda idiler. Öte yandan Isfahan'ın büyükleri ve ileri gelenleri sultanın veziri Sa'd el-Mülk-i Âbi'yi Batınîlikle itham ediyorlar, Muhammed Tapar'ın ona tam bir itimadı olduğundan onlara inanmıordu. Ancak vezir Batınîlere yiyecek ve ihtiyaç duydukları malzemeleri yollamakta idi. Muhammed Tapar ise son derece hararetli bir tabiata sahipti, bu nedenle her ay kan aldırırdı. Sa'd el-Mülk Şahdiz'deki Batunîleri kurtarmak maksadıyla sultanın kan alan hacamatçısı ile anlaşt ve ona Muhammed Tapar'ı öldürmek için bin dinar ${ }^{48}$ rüşvet ve zehire batırılmış bir neşter verdi. Fakat

${ }^{46}$ Bk. İbn el-Esir, X, s.297/Trk.trc., X, s.246; Abbas Íkbal, Vezaret, s.284- 295; Özaydın, Berkyaruk, s.64-65. Buna mukabil Sadr el-Dîn Huseynî (Ahbâr, s.88/Trk.trc., s.61), Habeșî b. Altuntak'ın yakalanıp Sencer'in ónüne getirildiğini, onun da yüz bin dinar aldıktan sonra
Habeșî'yi öldürdüğünü zikrediyor.

${ }^{17}$ Bk. İbn el-Esir, X, s.324, 378/Trk. trc., X, s.266 ve 306; B. Lewis, Hașişîler, Trk. trc., A. Aktan, İstanbul 1995, s.45; Özaydın, "Sultan Berkyaruk Devrinde (1092- 1104) Batunîlerle Yapılan Mücadeleler", Prof. Dr. Fikret Ișıltan'a 80.Doğum Yilı Armağanu, İstanbul 1995, s.183-
184.

${ }^{48}$ Taneri ("Vezirlik", s.178 not 452), Mumcu (aym eser, s.75) ve Özaydin, A., (Sultan Muhammed Tapar Devri Selçuklular Tarihi (498-511/1105-1118). Ankara 1990, s.81) verilen bu rüşeti on bin dinar olarak gösteriyorlar. Ancak onlann bu konuda gösterdiği kaynaklardan Ravendî (s.160/Trk. trc., I, s.55), el-Uraza (s.89) ve Reşid el-Dîn'in eserinde (Cami' Al-Tavârih, 
Sa'd el-Mülk'ün hacibinin karısının bu suikast tertibini sevgisine açıklaması, durumun sultana kadar ulaşmasına sebep olan olaylanı başlatmışu. Sonuçta rüşvetle sultanı öldürmek isteyen Vezir Sa'd el-Mülk ve hacamatçı aynı akıbete uğrayarak öldürüldüler ${ }^{19}$.

Muhammed Tapar dönemindeki bir diğer olay da yine vezir ile ilgilidir. Sultanın veziri Hace Ziyâ el-Mülk Ahmed b. Nizâm el-Mülk Hemedan reisi 'Alâ el-Devle'nin atası Seyyid Ebû Hâşim el-Huseynî'ye muhtemelen düşman idi ve aleyhinde çalışmağa başlamışu. Nitekim o Seyyid'i kendi eline teslim etmesi şartıyla sultana beş yüz bin dinar kazandırmayı taahhüt etmişti. Sultan bu rüşvet teklifine olumlu cevap vermiş olmalı ki, daha Seyyid'i yakalamak için hiç kimse Hemedan'a gitmeden önce o bu durumu haber aldı ve derhal harekete geçerek bilinmeyen bir yoldan bir haftada Isfahan'a ulaştı. Gece vakti kendisini Muhammed Tapar'ın yanına götürecek sultanın havasından bir hizmetkâr (hadim) aradı. Ona Lala Karategin'i önerdiler, Seyyid hayatunı kurtarabilmek için rüşvete karşı aynı silâhla mücadeleye başlamış, Karategin' e kendisini bu gece gizlice sultanın huzuruna götürmesi karşılığında on kese içinde on bin dinar rüşvet teklif etmişti, Karategin bu isteği yapmayı kabul etti, aymı gece onu sultanın huzuruna çıkardı ${ }^{50}$. Bu sırada sultanın eşi Kutlug•Han da orada idi ${ }^{51}$. Seyyid sultana eşi bulunmayan bir büyük inci getirmişti ve ağlayarak, "Bir süreden beri Hace Ahmed benim ocağımı yıkmak istiyor. Duydum ki, beni beş yüz bin dinara saun almıştur... onun benim elimle bırakılması şartıyla kulunuz bu beş yüz bin dinarı sekiz yüz bin ${ }^{52}$ yapacaktur" dedi. Sultan bu rüşvet teklifini, kaynağın ifadesiyle ${ }^{53}$, paraya düşkünlüğü sebebiyle kabul ve vezirini de feda etmişti. Nitekim Seyyid Ebû Hâşim Hemedan'a geri döndü, parayı hazırladıktan sonra seksen tane sandık yapıldı ve Buhara kumaşından torbalar dikildi. Her bir torbaya on bin dinar

II. Cild 5. cüz Selçuklular Tarihi, Yay. Ahmed Ateş. Ankara 1960, s.73) bin dinar olarak geçiyor. İbn el-Esîr (el-Kâmil, X, s.437/Trk. trc., X, s.346 ve devamı.) bu olayı zikretmiyor. Hamdullâh Müstevfí (Tarih-i Güzide, s.445), paradan bahsetmiyor. Buna mukabil Handmîr (Dustûr ef Vüzerâ, nşr. Sa'id Nefisî. Tahran hş. 1317, s.184) bu rakamı üç bin dinar olarak kaydediyor.

49 Bk. Ravendî, s.160/Trk. tr. I, 155; el-Urazâ, s.89; Reşid el-Dîn, s.72; Hamdullâh Müstevfi, s.445; Handmir, ayn eser, s.184; Özaydın, Muhammed Tapar, s.80-81.

${ }_{50}$ Bazı emîrlerin öldüklerinde geride bıraktakları yüklü miktardaki servetin nedenlerinden biri de bu tip rüșvetler olmalıdır.

${ }^{51}$ Bk. Ravendi, s.163/Trk. trc. I, s.159.

52 Bk. Ravendî, aynı yer; el-Urazâ, s.92- 93; Hamdullâh Müstevfi, s.446- 447. Buna mukabil Bundarî (s.98/Trk. trc. s.100) bu miktarı yedi yüz bin dinar olarak gösteriyor.

${ }^{53}$ Bk. Ravendî, s.164/Trk. trc., I, s.159. Yine Ravendî sultan için servet ve mal toplamağa düşkünlüğü vardı demektedir. 
konularak sandıklara yerleştirildi. Her iki sandık bir katıra yüklendi. Böylece kırk katıra sekiz yüz bin dinar yüklenerek parayı almağa gelmiş görevli gulam $^{54}$ ile yola çıkarıldı. Seyyid ayrıca gulama da bin dinar vermiști ${ }^{55}$. Sultan para eline ulaştuğında, Vezir Ziyâ el-Mülk Ahmed'i Seyyid'in eline verdi. O da intikamını aldı. Vezir, Seyyid için ne düşündü ise kendi başına geldi. Burada kazançlı çıkan sekizyüzbin dinar rüşveti alan Muhammed Tapar olmuştur ${ }^{56}$.

Her ne kadar Ravendî'nin verdiği bilgiye göre Seyyid, Ziya el-Mülk'den intikamını aldı görünüyorsa da, Mumcu (s.75- 76)'nun iddia ettiğinin aksine, öldürttüğü hususunda bir bilgi vermiyor. Çünkü Ziyâ el-Mülk'ün ölümü hakkında farklı rivayetler vardır ${ }^{57}$. Burada Bundarî'nin ${ }^{\text {tk }}$ verdiği bir bilgiden yararlanırsak, muhtemelen Seyyid onun azline sebep olmuş ve işten el çektirildikten sonra Ziyâ el-Mülk on iki yll hapiste kalmıştı. İbn el-Esir ${ }^{5 !}$ ise, Sultan Muhammed Tapar'ın h.500 Şevval ayında/Mayıs-Haziran 1107'de Sa'd el-Mülk Ebu'l-Mehasın'ı vezirlikten azlettiğini ve yerine Ahmed b. Nizâm el-Mülk'ü tayin ettiğini belirtiyor. Aynı müellife göre Ahmed b. Nizâm el-Mülk'ün vezirlikten azli h.504/m.1110- 1111 yllndadır. O daha sonra Ekim 1112'de Halife Müsterşid'e vezir tayin edildi ${ }^{60}$. Yaklaşık bu on iki ylllık süre Bundarî'nin verdiği bilgiye uygun düşüyorsa da İbn el-Esîr' in rivayetini göz önüne alırsak o azlinden sonra Bağdat'a gelerek bu şehirde yaşamış olmalıdır.

Öte yandan Seyyid Ebû Haşim öldükten sonra onun servetinden sultanın hazinesine iki yüz elli bin dinar nakledildi. Muhammed Tapar Hemedan'ın reisliğini onun oğluna verdi. Belki de bu para Seyyid'in oğlunun şehrin reisliğine tayin için verilen rüşvetten başka bir şey değildi ${ }^{61}$.

${ }^{54}$ Bundari'ye göre (s.98/Trk.trc. s. 100) bu görevli Enuşirvan b. Hâlid idi. Ravendî (s.164/Trk. trc. I, s.160) ve el-Urazâ (s.93)'da bu görevli şıhney-i hazine idi. Mirhond (IV, s.309) ise gulâm-ı ez hâzinân olarak zikrediyor.

${ }^{55}$ Handmîr (aym eser, s.186) para vermediğini belirtiyor.

${ }^{56}$ Bk. Ravendî, s.162- 165/Trk. trc. I, s.159-161; Bundarî, s.98/Trk.trc.s.100; el-Urazâ, s.9293; Hamdullâh Müstevfi, s. 446- 447; Handmîr, Dustûr el-Vüzerâ, s.185- 186; Mîrhond, IV, s.308309; Mumcu, ayn eser, s.75- 76 .

${ }^{57}$ Bk. Tanerî, "Vezirlik", s.178.

${ }^{58}$ Bk. s.102/Trk.trc.s. 103.

${ }^{59}$ el-Kâmil, X, s.438 ve 483 /Trk.trc. X, s.351 ve 387 .

${ }^{60}$ Bk. aym eser, X, s.602/Trk.trc. X, s.476. Onun halifenin vezirliğinden azli Temmuz 1123 'den sonradır (aynı eser, X, s. 615/Trk. trc. X, s.486). Ahmed b. Nizâm el-Mülk'ün ölümü h. 544/m.1149- 1150 tarihinde vuku bulmuştur, bk. aym eser, XI, s.147/Trk. XI, s.132. Ayrıca bu olaylar için bk. Abbâs Ikbal, Vezâret, s.163-170.

${ }^{61}$ Bk. Bundarî, s.102/Trk. trc. s.103. 
Sultan Muhammed Tapar döneminde Isfahan'ın reisi Abdullâh el-Hatibî adlı hilekâr ve yalancı bir şahıstı. Buna rağmen Bağdad'da zaman-zaman büyüklerle görüşebiliyordu. O Halife Mustazhir'in kardeşi Hasan hakkında da dedikodu yapmış, "Sultan (Muhammed Tapar) ile aramızda halifenin kardeşi Hasan'ın lafı geçti. Sultan benden onu sordu” demişti. Halife bu dedikodudan ve kardeşine bir zarar gelmesinden korkmuş olmalı ki, Hatibî'ye rüşvet gönderip, kardeşini diline dolamasını engellemişti ${ }^{62}$.

Bir diğer rüșvet olayı Nizâm el-Mülk'ün oğullarıyla ilgili olarak tespit edilmektedir. Ahmed b. Nizâm el-Mülk'ün vezirliği sırasında ârız el-ceyş görevi Anuşirvan b. Hâlid'in uhdesinde idi. Vezirin kardeşi Şems el-Mülk hazineye iki bin dinar rüşvet vermiş ve bu göreve atanmışt $\mathrm{a}^{63}$.

Öte yandan Haçlılar da Müslüman kalelerini kuşattıklarında bundan vazgeçmek için rüşvet istedikleri olaylar görülüyor. Bunlardan biri h.501/m.1107- 1108'de Sultan Muhammed Tapar döneminde vuku bulmuştur. Haçlı kralı I. Baoudouin zikri geçen sene içinde Sur şehrine yürüyerek burayı bir ay boyunca kuşattı. Ancak Sur valisi yedi bin dinar vererek onu çekilmeğe razı etmiş, Baudouin bu parayı alarak oradan uzaklaşmıştu ${ }^{\text {in }}$.

\section{Sultan Sencer Dönemi}

Bir tüccar olan Nizâm el-Dîn Togan Beg Muhammed b. Süleyman elKaşgarî Karahanlı hükümdarlarından birine vezirlik yapmıș, daha sonra Türkistan'dan Merv-i Şâhcân'a gelmişti. O burada Sultan Sencer'in yakınlarının yanında kendisine yer buldu. Türkçe bilmesi, ayrıca mal sarf etmesi ve rüşvet yoluyla sultanın mizacına uygun hizmetlerde bulunması nedeniyle akranlarından ayricalıklı oldu. Togan Bey daha sonra devletin ileri gelenlerinden özellikle Emîr Kumaç'a da lâyı hizmetler yaptı. Ebû Tahir Sa'd b. Ali el-Kummî'nin 15 Muharrem 51655/m.12 Mart- 10 Nisan 1112'de ölümünden sonra Emîr Kumaç sultanın vezirliğini bir milyon (be-hezâr

${ }^{62} \mathrm{Bk}$. ayn eser, s.95/Trk. trc. 97.

${ }^{63}$ Bk. aynı eser, s.100/Trk. trc. s.101. Ayrıca bk. Özaydın, Berkyaruk, s.170, 179. Ancak burada Șems el-Mülk'ün kardeşi Ahmed'e rüşvet verdiği zikredilmektedir.

${ }^{64} \mathrm{Bk}$. İbn el-Esir, X, s.455- 456/Trk. trc. X, s.364. İbn el-Esir'in bu rivayetine mukabil, Baudouin 1106'da Sayda'yı kuşatmış ve buranın valisinin kendisine gōnderdiği büyük miktarda para ile bu şehri iki yıl süreyle kendi haline bırakmışu, bk. S.Runciman, Haçh Seferleri Tarihi, çev. F. Işılltan, Ankara 1987, II, s.75.

65 Bundarî'nin eserinin Türkçe tercümesinde h. 519 şeklinde zikredilmiştir (s.241). Arapça metinde (s.267) h.516 yılı olarak geçiyor. 
hezâr) Nişabur dinarına rüşvetle onun için satın aldı. Böylece Togan Bey Muharrem ayında vezirlik hil'atini giydi. İki yıldan biraz fazla vezirlik yaptıktan sonra azledildi (h.618 Safer ${ }^{66} / 20$ Mart- 17 Nisan 1124) ${ }^{67}$.

Sultan Sencer döneminde rüşvetle ilgili bir olay Batınîler ile Emîr Erkuş arasında vukû bulmuştur. Selçuklu sultanına bağlı bir grup asker h.528/m.1133- 1134 yilında Emîr Erkuş kumandasında Batınîler'in elinde bulunan Horasan'daki Girdkûh kalesini kuşatmıştı. Emîr Erkuș'un bu kuşatması Batınîleri çok güç durumda bırakmışt ve kale ele geçmek üzere idi. Ancak rivayete göre Emîr Erkuş Batınîler'den pek çok para ve değerli takılar alarak kuşatmayı kaldırıp gitmiş, kaledekiler de kurtulmuştu ${ }^{6 i 8}$.

Sencer, veziri Nasır el-Dîn Mahmûd b. Muzaffer b. Ebî Buye (veya Ebî Tevbe)'yi azlettikten sonra ona divan-ı işraf-ı memâlik başkanlığı görevini vermişti. Babasıyla beraber oğlu Hace Şems el-Dîn Ali de bu divana dönmüş̦tü. Öte yandan bu dönemde Sencer'in ileri gelen emîrlerinden Cevher müsaadesiz ve tevki'siz bir çok ikta'yı gasp etmişti. Nasır el-Dîn bu durumu açıkladığında, Emîr Cevher taraftarları onu engellemek istedilerse de başarılı olamadılar. Ancak daha sonra Cevher, Emîr Ali Çetrî'nin yardımıyla Sencer'e rüşvet olarak çeşitli hediyeler, bir çok mal göndererek sultanı rüşvet yoluyla istediklere razı ettiler. Sonuçta Nasır el-Dîn ve oğlunu öldürdüler ${ }^{69}$.

Belh civarında, Huttelan otlaklarında konar-göçer olarak yaşayan Oğuzlar Sencer'in mutfağına yılda yirmi dört bin koyun vermekle mükellef idiler. Oğuz isyanının başlamasına sebep olan ilk olay, Selçuklu sarayının mutfağına bakmakla görevli olan hansaların bu iş için gönderdiği tahsildarın (muhassıl) onlara kötü muamele etmesinin yanı sıra Oğuzlar'dan rüşvet istemesi nedeniyle gerçekleşmişti. Ravendî̀ye göre ${ }^{70}$, "O adam bunlardan rüşvet alacağını ümit ediyordu. Mesel, Rüşvet eyaletleri kötüleştirir, valileri

${ }^{66}$ Bundarî'nin eserinin Türkçe tercümesinde (s.242) sadece yll olarak geçiyor. Arapça metinde (s.267) Safer 518 şeklindedir.

${ }^{67}$ Bk. Bundarî, s.267/Trk, trc.s.241- 242; Seyf el-Dîn Hâcı b. Nizâm Akilî, Âsâr el-Vüzerâ, nşr. Mîr Celâl el-Dîn Hussaynî Urmevî (Muhaddis, Tahran 1959, s.236); Handmîr, Dustûr elVüzerâ, s.191- 192; Abbâs İkbal, Vezâret, s.252- 253; Tanerî, "Vezirlik", s.96.

${ }^{68}$ Bk. İbn el-Esîr, XI, s.17/Trk. trc., XI, s.27. Krş Menuçher Sutûde, Kıl'a-ı Ísma'iliyye, Tahran hş. 1345, s.151. Ancak bu eserde rüşvet zikredilmiyor.

${ }^{69}$ Bk. Nâsır el-Dîn Münşî Kirmanî, Nesâim el-Eshâr, s.69; Akilî, Âsâr el-Vüzerâ, s.252- 253.

${ }^{70}$ Bk. Ravendî, s.177/Trk. trc. I, s.173; Mirhond, IV, s.315 vd.; Köymen, M. A., Büyük Selçuklu İmparatorluğu Tarihi, İkinci İmparatorluk Devri, Ankara 1984², s.406 vd. 
bozar". Onlar rüșvet vermediler". Böylece tahsildarın öldürülmesiyle başlayan olaylar zinciri Sultan Sencer'in esir edilmesiyle son bulmuştu (1153).

Öte yandan bu konuda İbn el-Esîr'in ilk rivayeti biraz farklıdır. Buna göre ${ }^{71}$, Belh ikta'ı sahibi olan Emîr Kumaç onları yaşadıkları yerlerden uzaklaştırmak istedi, ancak Oğuzlar bazı armağanlar vererek onunla anlaştlar. Emîr Kumaç daha sonra tekrar onların üzerine yürüdü ve kendi ıkta alanından çekip gitmelerini istedi. Oğuzlar direnerek bir araya geldiler. Kumaç ise on bin ath ile onlarmn üzerine doğru harekete geçti. Oğuz beyleri bu kez otlaklarında bırakılmaları karşılığında her aile için kendisine iki yüz dirhem gümüș teklif ettiler. Fakat Emîr Kumaç bu teklifleri kabul etmemiş, iki taraf arasındaki savaşı Oğuzlar kazanmıştı. Burada başlangıçta Oğuzlar'dan rüşvet alan fakat ikinci kez yapılan teklifi kabul etmeyen Emîr Kumaç bir ölçüde suçludur. Nitekim o ve oğlu Alâ el-Devle Ebû Bekr Oğuzlar ile yaptıklanı savaşta öldürülmüșlerdir. Bu haber Sultan Sencer'e ulaştğında Oğuzları tehdit ederek ülkesinden ayrılmalarını emretti. Oğuzlar özür dileyerek otlaklarında bırakılması karşılığında sultana pek çok mal (rüşvet) vermeği teklif ettiler ${ }^{72}$. Sonuçta Sencer ordusuyla Oğuzlar'm üzerine yürüdü ise de mağlup oldu ve esir düştü (1153).

${ }^{71}$ Bk. el-Kâmil, XI, s.176 vd./Trk.trc. XI, s.154-157.

${ }^{72}$ Bundarî'ye göre (s.282/Trk. trc. s.253) onlar Sultan Sencer'e elli bin at ve deve, iki yüz bin rüknî dinar, iki yüz bin Türk koyunu (rüşvet) teklif etmişlerdi. 


\section{Irak Selçuklulan}

\section{Sultan Mahmud Dönemi}

Sultan Muhammed Tapar vefat ettiği zaman (1118), oğlu Mahmud tahta oturtulmuş, ancak Horasan'ı yöneten amcası Melik Sencer buna itiraz etmişti. Her iki taraf arasındaki Save Savaşı (1119)'nı Sencer kazanarak sultanlığını ilân ederken, Mahmud da savaş meydanından kaçııștı. Bu sırada ortaya çıkan devlet adamı Kıvam el-Dîn Ebu'l- Kasım Ali Dergüzinî Enesâbadî herkesten önce davranarak, efendisi Mahmud'un işini yoluna koymak için Sencer'in yanına gitti. O Mahmud'un hazinesinden çarpmış olduğu maldan bir miktarını beraberinde götürdü, onları bol- bol dağıttı ve önünde engel gördüğü her şeyi rüşvet vererek (mali kesir be-rüşvet be-in ve an dâd) ortadan kaldırdı. Bu sayede Sencer ile Mahmud arasında aracılık yapmağı muvaffak oldu ${ }^{73}$. Böylece Irak Selçuklu Devleti'nin başlangıcında rüşvetle ilgili olarak iki şahsiyet ortaya çıktı. Bunlardan birisi Sultan Mahmud'un kendisine vezir tayin ettiği Dergüzinî idi.

Mahmud daha sonra Büyük Sultan Sencer'e karșı Halife Müsterşid ile bir ittifak oluşturmuştu. Fakat Sencer'in duruma müdahale ederek bir mektup göndermesi üzerine Mahmud Ocak 1127 başlarında Bağdad'a gelerek halifeyle savaştı. Sonuçta iki taraf bir anlaşma yaptılar. Öte yandan halife, Bağdat'a ulaşmadan önce Sultan Mahmud'a bir elçi göndererek ülkenin Dübeys b. Sadaka yüzünden perişan bir durumda olduğunu ve gelişini durum düzelinceye kadar tehir etmesini istemiş ve bu öneriye uyduğu takdirde bol miktarda para vermeği (rüşvet) vaat etmiştit ${ }^{74}$. Mahmud Rebi I. 521/17 Mart - 15 Nisan 1127 tarihine kadar Bağdad'da kaldı. Halife ona anlaştukları miktarda para gönderdiği gibi silâh, at ve saire de hediye etmiști. Sonuçta sultan halifeden anlaşma karşılığı bir miktar para (rüşvet) almıştı. Daha sonra hastalanan Mahmud Bağdad'ı terk ederek Hemedan'a gitti.

Bu olaylar sırasında Vezir Dergüzini halifeden rüşvet almak ve Sultan Mahmud'un Bağdat'tan çıkmasını temin etmekle itham edilmişti. Mahmud Bağdad'dan ayrıldıktan sonra Dergüzinî'yi Hemedan'da görevden azl ve hapsetti (Receb 521/Temmuz/Ağustos 1127) ${ }^{75}$.

${ }^{73}$ Bk. Bundarî, s.126- 127/Trk. trc. s.122; Abbâs İkbal, Vezaret, s. 266.

${ }^{74} \mathrm{Bk}$. İbn el-Esîr, X, s.635-638/Trk. trc., X, s.502- 504; Köymen, II. İmparatorluk, s.90n.

${ }^{75} \mathrm{Bk}$. İbn el-Esîr, X, s.642/Trk.trc.X, s.507-508; Köymen, ayn eser, s.111; Kayhan, H., Irak Selçuklulan (514-590/1120 1194), Konya 2001, s.63. 
Bir süre sonra Bat'daki işleri düzenlemek için Rey şehrine gelen Sultan Sencer burada Mahmud ile görüştü. Ayrıca Sencer Dergüzinî'yi desteklemekte idi ve onun emri ile sabık vezir serbest bırakıldı. Dergüzinî önce Sultan Mahmud'un eşinin yani Sencer'in kızının vezirliğine tayin edildi, sonra da Mahmud ona tekrar vezirlik görevi verdi. Bu göreve tayinde Dergüzinî Büyük Hacib Urgan (?)'1 rüşvetle kendi tarafina çekmişti. Muhtemelen Hacip Urgan Sultan Mahmud'u etkilemiş, böylece Dergüzinî tekrar vezirliğe tayin edilmişti (24 Muharrem 523/17 Ocak 1129) ${ }^{76}$.

Dergüzinî, kaynağın ifadesiyle, içi kötülük ve fesadla dolu bir şahıs idi. Onun hoşlanmadığı şahsiyetlerden biri de Aziz el-Dîn Isfahanî idi. Dergüzinî, Sultan Mahmud'a "eğer Aziz'i hapsedecek olursan, kendi malımdan üç yüz bin dinar veririm, onu hapse attı̆̆ın gibi malı ödemeğe başlarım" dedi. Bunun üzerine Bağdad'da iken sultan mala (paraya) meyl etti ve Aziz'i evinden çağırtarak muhafaza altına alınmasını emretti (h. 525 başları/1131 başları) ${ }^{77}$. Ancak Dergüzinî bu rüşveti kendi parasından değil, yaptığı müsadereler ile parça- parça ödemeğe başlamış, fakat vaat ettiği miktarı tamamlayamadan Sultan Mahmud ölmüştü (10 Eylül 1131).

Irak Selçukluları döneminde rüşvet olaylarına karışan ikinci şahıs Dübeys b. Sadaka idi ${ }^{78}$. Dübeys Sultan Mahmud'a isyan etmesi için Melik Mes'ûd'u kışkırtmıştu. Fakat Esedâbâd'da iki kardeş arasında yapılan savaşı (14 Haziran 1120) Mahmud kazandı. Bu sırada Dübeys Irak'da bulunuyordu ve Halife Müsterşid'i de tehdit etmişti. Mahmud Eylül-Ekim 1120'de Bağdat'a ulaştuğında, Dübeys karısını pek çok para ve hediyelerle sultanın yanına gönderip aff diledi. Onun bu dileği şartı olarak kabul edildi. Dübeys ise bu şartlı affı kabul etmemişti ${ }^{79}$.

Sultan Mahmud dönemindeki bir diğer olaya gelince, Vezir Kemâl Ebû Talib el-Sumeyremî Batunîler tarafindan öldürüldüğünde (Safer sonu 516/9

${ }^{7 t}$ Zubdet, s.151/Trk. s.143; İbn el-Esîr, X, s.652/Trk. trc. X, s.515; Köymen, ayn eser, s.123- 124; Abbâs İkbal, aynı eser, s.268; Ôte yandan İbn el-Esir başka bir yerde (X, s.642/Trk. trc. X, s.508) Sencer'in Zilhicce aynda (Kasım- Aralık 1128) hapisten çıkarıp tekrar Mahmûd'a vezir tayin ettiğini belirtiyor.

77 Bk. Zubdet, s.153-154/Trk. trc. s.145- 146; Abbâs İkbal, ayn eser, s.269.

${ }^{78}$ Hayau için bk. Özaydın, A., Dübeys b. Sadaka mad., DiA.

79 Bk. Biyografilerle Selçuklular Tarihi İbnü'l-Adîm Bugyetü't-taleb fí Tarihi Haleb (Seçmeler). Ceviri, notlar ve açıklamalar, Ali Sevim, Ankara 1982, s.140; İbn el-Esir, X, 565- 566/Trk. trc.X, s.449; Sevim. A.-Merçil, E., Selçuklu Devletleri Tarihi, Ankara 1995, s. 233. 
Mayıs 1122) ${ }^{80}$, Mahmud onun yerine yedi yüz bin dinar (rüșvet) veren Șems el-Mülk Osman b. Nizâm el-Mülk'ü tayin etmişti ${ }^{81}$.

İmâd el-Dîn Zengi'nin Musul ve çevresine vali atanmasıyla ilgili olaylarda da rüşvet teklifi rol oynamış olmalıdır. Musul hâkimi İzz el-Dîn Mes'ûd b. el-Porsukî'nin ölümüyle $(521 / 1127)$, yerine küçük kardeși geçti. Ülkeye ise Aksungur'un Çavlı adındaki memlûkü hâkim olmuştu. Çavlı Sultan Mahmud'a elçi gönderip ülkeyi Porsukî'nin oğluna vermesini istedi ve bu iş için ona pek çok mal vermeyi vaat etti. Ancak Çavlı'nın bu iş için gönderdiği elçiler Sultan Mahmud'a aralarında İmâd el-Zengî'nin bulunduğu birkaç kişiden bahsettiler Ayrıca "Sultanın hazinesine yaklaşmak maksadıyla İmâd el-Dîn adına pek çok mal (para) vermeği vaat ettiler". Bunun üzerine Mahmûd, Zengî'nin vali tayin edilmesini kabul etti ${ }^{82}$.

Bir ara Haleb'de karışıklıklar çıktı. Haçlılar bu haberi duyunca Joscelin askerleriyle Haleb'e hareket etti. Şehir halkı ona biraz para verip anlaşmıș, Joscelin de geri dönmüş̧ü (takriben Ekim- Kasım 1128) ${ }^{83}$.

Melik Tuğrul ile Dübeys de birleșerek Irak Selçuklu tahunı ele geçirmek istemiș, fakat başarılı olamayarak Sultan Sencer'e sığınmak zorunda kalmışlardı. Bundarî'ye göre ${ }^{84}$, daha sonra devlet ileri gelenleri, "Emir Dübeys'den rüşvet aldılar ve onu Irak'a gönderdiler". Tabiî o Sultan Mahmud ile beraber harekete geçerek Irak'a gelmişti (1129). Sultan Mahmud, amcası Sencer'in talimatıyla, onu Halife Müsterşid'e aff ettirmek, ayrıca Zengî'nin yerine Musul'a atanmasımı sağlamak istiyordu. Ancak halife Dübeys'in affina ve Zengî'nin yerine atanmasına karşı çıktı, hatta buna engel olmak için yüz bin altun (rüşvet) vermeyi önerdi ${ }^{85}$. Atabeg Zengî de

${ }^{80}$ Bk. İbn el-Esîr, X, s.601/Trk. trc.X, s.475. Buna mukabil Anonim Mücmel Terarih (nşr. Melik el-Su'ara Bahar, Tahran hş. 1318, s.414)'e göre, bu olay Safer 515/Nisan-Mayıs 1121'de vuku bulmuştur.

${ }_{81}^{81}$ Bk. Mücmel el-Tevârih, s.414. İbn el-Esîr, ayn yer. Ancak bu eserde rüşvet zikredilmiyor.

${ }^{82}$ Bk. İbn el-Esîr, X, s.643-645/Trk. trc.X, s.508-509. Alptegin, C., The Reign of Zangi (521-541/1127-1146), Erzurum 1978, s.28; İmâd el-Dîn Halil, İmâd el-Dîn Zengi. Beyrut 1971 . s. $42-44$.

${ }^{83}$ Bk. Ibn el-Esîr, X, s.650/Trk. trc. X, s.514. Runciman'a göre (Haçlı Seferleri, II, s. 148) bu olay 1127 olarak verilirken, para sōz konusu edilmiyor.

${ }^{81}$ Bk. s.121/Trk. trc.s.118.

${ }^{85}$ Bk. İbn el-Esîr, X, s.654/Trk. trc. X, s.517; Köymen, II. İmparatorluk, s.135n ve s.137. 
Dübeys'in Musul'a atanacağını öğrendiğinde, o da bu tayini engellemek için Sultan Mahmud'a yüz bin altun (rüşvet) vermiş̧ti ${ }^{86}$.

Daha sonra gelişen olaylar sonucu ve Mahmud'un ağır bir şekilde hastalanması, Dübeys'in aradığı firsatı bulmasına ve sultanın küçük oğlu Ferruhşâh'ı da yanına alarak Hille'ye yürümesine sebep oldu. O hiçbir direnişle karşılaşmadan eski başkenti Hille'ye girdi (Ağustos-Eylül 1129). Dübeys, Mahmud'un Hemedan'dan Bağdad'a geldiğini haber aldığı zaman, sultana bol miktarda hediyeler, altun nallı üç yüz at ve iki yüz bin dinar gönderip ondan ve halifeden aff diledi. Fakat Sultan Mahmud onun bu isteğini kabul etmedi ${ }^{87}$.

Bir süre sonra Dımaşk atabeyi Böri Dübeys'i tuzağa düşürerek ele geçirdi. Durumu öğrenen Zengî düşmanı olan Dübeys'i, elinde tutsak bulunan Böri'nin oğlu Sevinç ve bazı emîrleri serbest bırakmak ve elli bin altın karşılığ ${ }^{88}$ Böri'den (rüşvetle ?) satın aldı (Kasım 1131) ${ }^{89}$. Burada kaynakların değişik ifadeleri karşısında bu olayı bir rüşvet olarak kabul edebilirmiyiz? Azimî; Böri'nin Dübeys'i oğlu Sevinç'in fidyesi karşılığında atabeye verdi, şeklinde bir ifade kullanyor. İbn el-Adim'in ifadesi ise, satmak veya satun almak şeklindedir. İbn el-Esîr'e göre, Böri Dübeys'i tehditle Zengi'ye göndermişti.

\section{Sultan II. Tuğrul Dönemi}

II. Tuğrul, Sultan Sencer tarafindan h.526 Cumada II/Nisan-Mayıs 1132'de Irak Selçuklu tahtına oturtuldu. Sencer ayrıca Dergüzinî'yi ona vezir tayin etmişti" ${ }^{90}$. Daha sonra Halife Müsterşid, Köymen'e göre" ${ }^{91}$, Bağdad'a girebilme şartlarını bildirmek üzere II. Tuğrul'a elçiler gönderdi. Selçuklu veziri onları soğuk bir şekilde karşılamış yüzlerine karşı münasebetsiz sözler

${ }^{86}$ Bk. İbn el-Esîr, X, s.654/Trk. trc.X, s.517; Köymen, aynı eser, s.137; Alptegin, ayn eser, s.33.

${ }^{87}$ Bk. İbn el-Esîr, X, s.655/Trk. trc. X, s.518; Köymen, (aym eser, s.147n.2). Köymen Sıbt'dan naklederek, sultana 55 Arap tayı, üç katur yükū para (emval)-200.000 dinar, Halife'ye de 3000 cins at verileceğini zikretmektedir; Sevim-Merçil, Selçuklular Tarihi, s.240.

${ }^{88}$ Bir rivayete göre Zengi yüz bin altun vererek onu almışt, bk. Biyografilerle Selçuklular Tarihi, s.144 ve 152 .

${ }^{89}$ Bk. Ibn el-Esîr, X, s.668/Trk. trc. X, s.527; Özaydın, Dübeys b. Sadaka mad., DIAA; Alptekin, Zengi mad., IA.

${ }^{90}$ Bk. Bundarî, s.160/Trk. trc.150; İbn el-Esîr, X, s.678/Trk. trc, X, s.534; Köymen, aynı eser, s.197-198

${ }^{91}$ Bk. I. Tuğrul mad., IA., s.16. 
söylemek terbiyesizliğini göstermişti. Bundarîn", "rüşvet tamahı ile" onun düzgün olan işi bozduğunu zikrediyor. Bu sebeple halife ile sultan arasında hiçbir anlaşma kararlaştırılmadan elçiler geri gitmişlerdi. Belki de vezir halife tarafından, sultanla arasında arabuluculuk yapması için, kendisine hediye (rüşvet) gönderileceğini ümit etmiş, düşündüğü gerçekleşmeyince de elçilere kötü davranmıştı.

\section{Sultan Mes'ûd Dönemi}

Râşid halifelikten azledildikten sonra, yerine geçecek biri arandığında, Vezir Şeref el-Din Zeynebî bu konuda etkili olmuş ve Sultan Mes'ûd'a Râşid'in amcası Ebû Abdullah'ı önermişti. Sultan Mes'ûd ile vezir daha sonra huzuruna girip onunla anlaştılar. Vezir ikisi arasında kabul edilen anlaşma maddelerini karara bağlayıp açıkladı. Böylece 18 Ağustos 1136 'da Ebû Abdullâh "el-Muktefî li-emrillâh" lâkabıyla halife ilân edildi"3 . Ebu'l-Ferec'e göre ${ }^{94}$, bu anlaşma sırasında, Muktefi sultana yüz on iki bin dinar verdikten sonra tahta oturmuştu.

Sultan Mes'ûd Kasım 1138 tarihinde vezirliğe Kemâl el-Dîn Muhammed Hâzin'i tayin etti. Yeni vezir gayet başarılı olup, devlet işlerini düzene sokmuştu. Ayrıca o Mes'ûd'u Azerbaycan'ı yöneten Atabeg Karasungur'un baskısından kurtarmağa çalıştı ve gizlice bu konuda sultanla anlaşu. Buna göre Karasungur veziri İzz el-Mülk Ebû İzz el-Bürücirdî'yi teslim edecek olursa ona beş yüz bin dinar verilecekti. Belki de sultan ve Kemâl el-Dîn, Karasungur'un bu yardımcısını bertaraf etmekle onu zor durumda bırakmayı plânlamışlardı. Bir diğer ihtimale göre, İzz el-Mülk Dergüzinî'nin arkasına takmış olduğu şeytanlardan biri olup birçok insanın emlâkini zabt etmişti. Sultan Mes'ûd ve Kemâl el-Dîn onun kötülüklerini önlemek istemişlerdi. Ancak Karasungur bu teklifi kabul etmemiş ve vezirini mal karşılığında feda etmemişti $^{95}$.

Sultan Mes'ûd zamanla Hasbeg Belengerî adlı emîrin mevkiini yükseltmişti. Bu olay sultanın yanında bulunan öteki emîrlere ağır geldi ve durumu Erran ve Azerbaycan'ı yöneten Çavlı Candâr'a şikayet ettiler. Cavlı

${ }^{92}$ Bk. Zubdet, s.160/Trk. trc., s.150.

${ }^{93}$ Bk. Bundarî, s.183/Trk.trc. s.169; İbn el-Esîr, XI, s.142-143/Trk. trc. XI, s.47.

${ }^{94} \mathrm{Bk}$. Abû'l-Farac Tarihi, Cilt II, Türkçe çvr. Ömer Rıza Doğrul, Ankara $1987^{2}$, s.372.

${ }^{95}$ Bk. Bundarî, s.186/Trk. trc. s.171,179; İbn el-Esîr, XI, s.64/Trk. trc.XI, s.65. Ancak İbn el-Esîr, rūşveti zikretmiyor. Sevim-Merçil, aynı eser, s.253- 254. 
da bu nedenle Hasbeg'i yakalamağa çalışıyordu. Bir gün Mes'ûd bunu haber alıp Çavlı'ya, "Ben seni düșmanlan uzaklaştırmak için çağırdım, emîr elümerâ yaptım. Sen ilk iş olarak benim hasekime hücum ediyorsun" diye haber yolladı. Çavlı sultanın bu haberi karşısında muhtemelen bașına gelebilecek tehlike nedeniyle, korktu. "Dergâhın eskilerinden olan Hâce Yakut'a sultanı böyle bir niyeti olmadığını ikna için on bin dinar (rüşvet) gönderdi” Hâce Yakut Çavlı adına özürler dileyerek sultanı iknaya muvaffak oldu ${ }^{9 t i}$.

Sultan Mes'ûd döneminde Rey şehrinde bir amid görev yapmıș ve bir yıl memuriyette bulunmuştu. $O$ bu süre içinde kendine yeter derecede servet toplamıştı. Muhtemelen sultan Irak'a geldiğinde bundan hesap soruldu. Amid bunun üzerine Bağdat halkından Hakimoğlu (İbn Hakim) diye meşhur olan bir müşrifi çağırtarak hesaplarındaki yolsuzlukları örtecek şekilde çalışmasını istedi. Buna mukabil müşrife iki bin dinar (rüşvet) önerdi. Ancak müşrif bunu kabul etmeyerek hesabı doğru bir şekilde yaptı. Daha sonra amid ve Hakimoğlu sultanın vezirinin karşısına çıkarak hesabı verdiler. Vezir İzz el-Mülk bu kez iyi niyetle hareket ederek hesabı uygun buldu. Amîd ve müşrif vezirin yamından çıktıktan sonra amid yine de Hakimoğlu'na altı yüz dinar vererek, "bu senin içindir, senin doğruluğundan bana zarar dokunmadı" demişti ${ }^{97}$.

\section{Sultan II. Muhammed Dönemi}

II. Muhammed Hemedan'da tahta oturduğunda (Şubat-Mart 1153), kardeşi Melikşâh'ı şehrin dışında bir köşke götürerek hapsetmişti. Fakat Melikşâh buradan kaçarak Huzistan'a gitti ve kardeşinin hükümdarlığı zamanında burada idi, çünkü ona karşı gelecek kuvveti yoktu. Kızkardeşi Gevher-Neseb Melikşâh'ın tarafında idi. Bu hâtun Melikşâh bir ordu meydana getirerek Muhammed'e isyan etsin diye Isfahan'dan Huzistan'a doğru ilerledi, beraberinde bu durumu rüşvetle sağlamak üzere çuvalla altun götürüyordu. Sultan II. Muhammed bu durumu haber aldığında, Atabeg Ayaz' 1 bir ordu ile göndererek o mal ile hazineyi yağma ettirdi ${ }^{98}$.

Sultan II. Muhammed Irak Selçuklu Devleti'nin önde gelen emîr ve zenginlerinden Hasbeg'i öldürtüp onun mallanna ve hazinesine el koymuștu. O Hasbeg'i ortadan kaldırdığı sırada kardeșlerinden Süleymanşâh



${ }^{97}$ Fazla bilgi için bk. Bundarî, s.197/Trk.trc.s.179- 180; Taneri, "Vezirlik", s.112- 113.

${ }^{9} \mathrm{~B}$ B. Ravendi, s. 255-256/Trk. trc. Il, s.245- 246; Mumcu, aynı eser, s.75.
} 
büyük bir ordu ile Hemedan'a yürüdü. Muhammed'in yanında küçük bir ordu vardı. Çünkü yakın adamları (hasekiyân), ordunun o dönemde âdeti olduğu üzere, anlaşmazlığa düşmüş ve dağılmışlardı. Sultan Muhammed onları yatışturmak için rüşvet olarak külâh-külâh altın, çuval- çuval elbise dağıtıyordu. Askerler bu dağıtılanları almalarına rağmen yine de kaçıyorlardı. Böylece Hasbeg'in hazinelerinin çoğu tükenmiştị?.

\section{Sultan III. Tuğrul Dönemi}

Sultan III. Tuğrul 1188/1189 kışını Hemedan'da geçirdiği sırada emîrler ile arasında anlaşmazlık çıkmıştı. Bu emîrler gizlice Rey'de bulunan Kutluğ İnanç'a kısa mektuplar göndererek sultana karşı harekete geçmeğe davet ediyorlardı. Ancak bu durum çok geçmeden ortaya çıktı. Onlar derhal aman diledilerse de sultan hepsinin yakalanmasın ve mallarmm müsaderesini emretti. III. Tuğrul kendisine ihanet edenleri Alâ el-Devle kalesinde hapsettirdi. Onlar bunun için aman dileyerek mal ve para vermeyi taahhütte bulunuyorlardı. Nitekim bunun için harekete geçilmiş, onlar borçlar alarak divana teslim ediyorlardı. Bir gün tutuklulardan Kutluğ Taşdâr kaleyi gezen sultana manasız sözler söyleyerek, "Atabeg Muhammed'in muvafakatı ile Hemedan reisi Alâ el-Devle babanın (Sultan Arslanşâh) karısı olan kız kardeşinin öcünü almak için bana on bin dinar verdi, ben de (zehirli) şerbeti hamama götürüp babana verdim. Senin de başına aynı şey gelecekti” dedi. Sultan III. Tuğrul bu durumda büyük bir kızgınlı̆̆a kapıldı ve tutukluların hepsini öldürülmesini emretti (Zilhicce 584/Ocak-Şubat 1189) ${ }^{100}$. Büyük Selçuklu Sultanı Muhammed Tapar zehirlenmekten kurtulabilmiş, buna mukabil Irak Selçuklu Sultanı Arslanşâh on bin dinar rüşvet karşılığı öldürülmüştü.

Sultan III. Tuğrul'un rüşvet aldığı şahsiyetlerden birisi de, Hemedan reisi Alâ el-Devle'nin oğlu Mecd el-Dîn idi. Mecd el-Dîn sultanın sevgililerinden olan Züleyha adlı bir çalgıcı ile Tuğrul'un haberi olmadan, işret (içki içmek) yapmıșt. Sultan bu durumu öğrenerek onu yakalamışt. Mecd el-Din muhtemelen canını kurtarabilmek için külçe hâlinde beş yüz bin dinar kızıl altun ödedi. III. Tuğrul onu, altınlarla beraber, esir olarak Kazvin (veya Ferrezîn) Kalesi'ne yolladi ${ }^{101}$.

\footnotetext{
${ }^{2 n}$ Bk. Ravendî, s.262/Trk. trc. II, s.252; Mumcu, aym eser, s.75.

${ }^{100}$ Bk. Ravendî, s.351- 352/Trk. trc. II, s.323- 324; Ravzat us-Safa, IV, s. 345; Sevim-Merçil, aynı eser, s.289.

${ }^{101}$ Bk. Ravendî, s.367/Trk. trc. II, s.337.
} 


\section{Türkiye Selçuklulari ${ }^{102}$}

Türkiye Selçuklulari'nda menşur yazan görevliye (tuğraî) rüşvet veriliyor mu idi?. Sultan II. İzz el-Dîn Keykavus tahta oturduğunda (1246) birçok göreve tayinler yapıldı. Buna göre vezirlik Sahib Şems el-Dîn Muhammed Isfahanî'ye, naiblik Celâl el-Dîn Karatay'a, Beylerbeylik Şems el-Dîn Hasoğuz'a, atabeylik Esed el-Dîn Ruzbeh'e ve pervanelik Ebû Bekr Attar'a verilmişi. Baba lâkaphı Şems el-Dîn Mahmud Tuğraî her birinin adına menşur yazdı. Bundan dolayı eline çok miktarda mal (para) geçti. Beylerbeyi Şems el-Dîn Hasoğuz, Anadolu halkı bu durumu öğrensin ve ona göre davransın diye yazacakları karşılığında ona elli bin gümüs para (adet) ödemeği kabul etti ${ }^{103}$. Belki de bu menşurun şatafatlı ve süslü kelimelerle yazılması halk üzerinde daha etkili olmakta, bu bakımından tuğraîye bunu sağlamak açısından para (rüşvet) verilmekteydi.

Daha sonra emîrler ve görevliler arasında çekişmeler başladığı zaman Pervane Ebû Bekr Attar ve Emîr-i dâd Nusret birleşerek Emîr Şems el-Din Hasoğuz ve emîr-i câmedâra tuzak kurarak öldürmüşlerdi. Bunlara karşı Sahib Şems el-Dîn Isfahanî, Şems el-Dîn Mahmud Tuğraî ve Erzincan Sübaşısı Şeref el-Dîn Mahmûd bir ittifak olușturdular. Ebû Bekr Attar gelișen olaylar nedeniyle, "gizlice fitne ve karışıklıkların kaynağı olan ve bazı hallerde kavgaları yatıştırmak için kendilerinden yardım istenen Konya ahîlerinin ve fityanlarının ileri gelenlerini çağırdı. Onları vaatler ve bağışlarla (rüşvet) kendisine bağladıktan sonra sultana karşı gelme ve ayaklanma konusunda yardım istedi. Ancak Konya ahîleri... sultana karşı ayaklanmaya kalkışamayız ve efendimizin nimetlerine nankörlük edemeyiz" dediler. Böylece Ebû Bekr Attar'in teklifini reddettiler ${ }^{104}$.

Bu üçlü ittifakın aralarındaki dostluk uzun sürmedi. Çok geçmeden Sahib Şems el-Din'in Sübaşı Şeref el-Din ile arası açıldı. Şeref el-Dîn'in Ahlat Meliki'nin torununu öldürmesi üzerine sahib onu kınadı. Sahibin bu çıkıșından korkan Şeref el-Dîn Erzincan yolunu tuttu. Sahib yerinde bir davranışla onun peşinden Emîr Tâc el-Dîn Simcurî ve Emîr Nizâm el-Dîn Ali b.

\footnotetext{
${ }^{102}$ Eğer na'l-baha terimini rüşvet olarak kabul edebilirsek bu konuda bk. Merçil, E., “Na'lBaha Ve Kullamılısıına Dair Örnekler", Belleten, Sayı: 227, Ankara 1996, s.21- 32.

${ }^{10{ }^{3}} \mathrm{Bk}$. İbn-i Bîbî, El-Evâmirü' 'l-'Alâ'iyye Fíl'-Umûri'l-Alâ'iyye, Önsōz ve fihristi hazırlayan A.Sadık Erzi, Tıpkıbasım Ankara 1956, s.550/Türkçe trc. Mürsel Öztürk, I-II, Ankara 1996, II s.89.

${ }^{104}$ Bk. aynı eser, s.563/Trk. trc. II, s.99; Turan, Selçuklular Zamanında Türkiye, s.461-462.
} 
İlalmıș'ı gönderdi. Bu iki emîr Şeref el-Dîn'in gitmesini zorla engelleyip durdurdular, uzun bir konuşma ve tartışmadan sonra Erzincan ve Niksar komutanlığına (serleşker) ilave olarak Emîr Şeref el-Dîn'e özel gelirlerden (vücuh-ı has) üç yüz bin dirhem (gümüş para) verilerek onunla bir anlaşma sağlandı $(644 / 1246-1247)^{105}$. Böylece ortaya çıkması muhtemel bir isyan ve kargaşa verilen rüşvetle geçici olarak önlenmişti.

Sahib Şems el-Dîn Isfahanî Selçuklu Devleti'ni tam iki yıl yönetmişti. Daha sonra Moğollar Selçuklu ülkesini Rükn el-Dîn IV. Kılıç Arslan'a vermişlerdi. Bu olay sahibin huzurunu kaçırdı, nitekim korktuğu başına geldi ve tutuklanarak öldürüldü. Bir süre sonra Sahib Şems el-Dîn olayını araşturmak ve öldürülüşüne duyulan rahatsızlığı bildirmek için Batu (Sayın) Han'ın huzurundan bir elçi grubu Anadolu'ya geldi. Bu durumda Şems elDîn Mahmud Tuğraî sorulara cevap vermek ve itirazları gidermek üzere çok miktarda malla Batu Han'ın huzuruna gönderildi. Mahmûd Tuğraî Batu Han'a giderken, Sahip Şems el-Dîn 'in adamlarını da yarlıg hükmünce bağlı olarak orduya götürdü. Orada Sahib Şems el-Dîn olayını araștırıp soruşturdular. İki tarafin mensupları da kendilerini kurtarmak ve emellerine ulaşmak için bol miktarda harcama (ihracat) yaptılar ve kendilerini kur$\operatorname{tard}{ }^{1}{ }^{106}$. Rüssvet bu olayda da işe yaramış ve Batu Han'ın huzuruna gidenler ayrıca kendilerine verilen yeni görevler ile Anadolu'ya dönmüşlerdi.

Öte yandan Atabeg Şems el-Dîn Altun-aba devlet yönetimi hakkında Sultan II. İzz el-Dîn Keykavus'a bazı nasihatlerde bulunmuştu. Bu nasihatlerden dolayı Kayseri Sübaşısı Seyf el-Dîn Türkeri'nin kalbinde atabege karşı bir kin uyandı. Onların arasinda daha önce de kırgınlık ve düşmanlık bulunması dolayısıyla öfkesi iyice artan Türkeri atabegin Fahr el-Dîn Belek adlı hacibine bol miktarda mal (para) vaat edip (rüşvetle) kendi tarafına çekerek Şems elDîn Altun-aba'nın içki testisine öldürücü zehir koydurdu. Atabeg onu içtikten sonra öldü $(1254)^{107}$. Rüşvet bir kere daha bir insanın ölümüne se-
bep olmuştu.

Hatiroğlu Ziya ile kardeşi Şeref el-Dîn Mes'ûd'un isyanı sırasında onlar Sultan Gıyâs el-Dîn Keyhusrev'i Niğde'ye göndermişlerdi. Sultan Niğde'de

\footnotetext{
${ }^{105}$ Bk. İbn-i Bibî, s.565- 567/Trk. trc. II, s.100-101. Ancak Türkçe tercümede bu rakam baskı hatası sonucu 500.000 olarak gösterilmiştir. Ayrıca bk. Turan, aynı eser, s.462.

${ }^{106}$ Bk. İbn-i Bibî, s.596- 597/Trk. trc. II, s.127-128; Turan aym eser, s.470.

${ }^{107}$ Bk. İbn-i Bibi, s.606-607/Trk. trc. 135; Turan, ayn eser, s.471- 472.
} 
bulunması dolayısıyla bu şehirde her sınıftan büyük bir kalabalık olıştu. Şeref el-Dîn'in her gün gücü, kibri, gururuyla birlikte aptal ve cahil hareketleri arttı. Ayrıca devlet büyüklerini zulüm ve baskı altunda tutuyordu. Atabeg Mecd el-Dîn Ebu'l-Hâmid Muhammed el- Erzincanî ile Müstevfî Celâl elDîn' in can güvenliği kalmadı. Onlar bu durum karşısında Șeref el-Dîn'e bol miktarda mal (para) göndererek (mal-ı bisyar/rüşvet) canlarını kurtarabildiler ${ }^{108}$. Rüşvet bu olayda can kurtaran bir rol oynamışt.

Şeref el-Dîn'in etrafinda Niğde'de her grup insandan büyük bir topluluk toplanmıştı. O nifak pazarını canlandırma, askerî görevlileri itaati altına almak için hepsinin isteğini yerine getirip onları amaçlarına ulaşturdı. Bu nedenle önemli kişilere geniş iktalar ve verimli araziler dağıttı ${ }^{109}$. O böylece çevresinde toplananları rüşvetle kendine bağlama yolunu tercih etmişti.

Öte yandan Alâ el-Dîn Siyavuş (Cimri)'un Konya'yı aldığını öğrenen Sahib Fahr el-Dîn'in oğulları Tâc el-Dîn Hüseyin ve Nusret el-Dîn Hasan asker topladılar ve bu orduya katılmaları için Germiyan Türkleri'ne ellibin dirhem (aded) dağıttular ${ }^{110}$ (1277).

Bu yıl içinde Abaka Han Muîn el-Dîn Pervane'yi Sultan Baybars ile işbirliği yaptığı için öldürtmüştü (2 Ağustos 1277). Pervane'nin ölümü hakkında çeşitli rivayetler vardır. Bunlardan birine göre ${ }^{111}$, Sahib Fahr el-Dîn Ali ölmeden önce Pervane'ye Moğollara mal (para) vererek hayatun kurtarmasını teklif etmişse de, o rüşvet vermeği reddederek bu teklifi "bu hayattan bıktım" diye cevaplamışt.

Baltu isyanının basturılması ve Sultan II. Mes'ud'un Gazan Han'm huzuruna gitmesiyle Anadolu dört malî bölgeye ayrılmış, bunlardan birine saltanat naibi unvaniyla Kemâl el-Dîn Tiflisî tayin edilmiști (1296). Daha sonra Kemâl el-Dîn Tiflisî kendi payına düșen Amasya ve Samsun bölgesine gitti. $\mathrm{O}$ Samsun'da iken, "oranın darphanesinin görevlilerinden şiddete ve zulme başvurarak aldığı rüşvet ve haracın kötülükleriyle kötülenmeyi içine sindirdi.

${ }^{108} \mathrm{Bk}$. İbn-i Bibî, s.665/Trk. tuc. II, s.182.

${ }^{109}$ Bk. aymı eser, s.687/Trk. trc. II., s. 202.

${ }^{110}$ Bk. ayn eser, s.698/Trk. trc. II, s.210.; Kaymaz, N., Pervâne Mu'înü'd-Dîn Süleyman, Ankara 1970, s.173.

${ }^{111}$ Bk. Anonim Selçuknâme, s.59/Trk. trc. s.38; Kaymaz, aynı eser, s.179 n.170. 
Rüşvetin ipiyle karanlıklar kuyusuna düştü. Bir avuç serserinin saf gümüşü, kalp para için kullanmalarına ve paranın ayarını bozmalarına izin verdi" 112 .

Anadolu dört bölgeye ayrildığında Cemâl el-Dîn Muhammed vezir olarak tayin edilmiş, ancak yönetimine verilen Diyarbekir bölgesine gelmekte gecikmişti. Bunlardan Isfahanlı, Hemedanlı, Hutenli memurlar halkı çeşitli bahanelerle soymuşlardı. Cemâl el-Dîn önce onları kendi tarafina çekmiş, sonra hesaplanı inceleme yoluyla onlara zarar vermek istemişti. Onlar da vezire rüşvet vaat ederek, yerlerinin değişmesini engellediler. Ayrıca özel gelirlerinin dışında ilave olarak onun hazinesine yüz bin dirhem vermek vaadiyle onu kandırarak halkı soymaya devam ettiler ${ }^{113}$.

İlhanlı Devleti'nin vergi düzenini sağlamak maksadıyla Anadolu'ya gönderdiği şahıslardan birisi Vezir Nizâm el-Dîn Yahyâ idi. Bu vezir Anadolu'da birçok kişiyi çeşitli bahanelerle soymuş veya mallanını müsadere etmişti. Bu dönemde ona yardımcı olan muhbirler de mevcuttu. Aksarayî bu durumu bir şiirle ifade ediyor,

"Eğer sen efendinin yakını olmak istiyorsan

Zulmü meslek edin ve Allah'tan korkma

Ona rüşvet ver ve sonra gözünün önünde karısına dokun ve korkma"

Ayrıca Aksarayî o günkü ortamı şu sözlerle açıklamağa çalışıyordu,

"Velhasıl herkes rüşvet ipiyle kese dokuyor,

her biri, kendi kazanı için dünyayı yakıyordu" "ı!

Türkiye Selçukluları'nın son yıllarında Anadolu'da otorite boşluğu yaşanmış, İlhanlı Devleti'nin gönderdiği görevliler ise gerek müsadere gerekse rüşvetle zengin olmanın yollarını aramışlar, bunun yükünü çeşitli bahaneler ile soyulan halk çekmişti.

Sonuç olarak rüşvetle ilgili bazı tespitler yapmamız mümkündür. Kaynaklardaki olaylara baktığımızda Büyük Selçuklu ve Irak Selçuklu sultanlarının rüșvet aldıkları tespit edilebilmektedir. Türkiye Selçukluları'nda na'l-

\footnotetext{
${ }^{112}$ Aksaraylı Mehmed oğlu Kerimüddîn Mahmûd, Müsâmeret Ül-Ahbâr, Ankara, s.271/Trk. trc. Mürsel Öztürk, Ankara 2000, s.178; Turan, Türkiye, s.621.

${ }^{11.3} \mathrm{Bk}$. Aksarayî, s.226- 227/Trk. trc. s.182; Turan, aynı eser, 621.

${ }^{114}$ Bk. Aksarayi, s.261/Trk. trc.s.210-211.
} 
bahayı hesaba katmazsak, az sayıdaki kaynaklarda, sultanların rüşvetle ilgisi hemen-hemen hiç zikr edilmemektedir.

Selçuklu sultanlarının eşleri de rüşvet alıp-veren şahsiyetler olarak karşımıza çıkıyor. Böylece hâtunların sultanlar üzerinde etkili olduklanı ve zaman- zaman aracı rolü üstlendikleri kendilerine verilen rüşvetlerden anlaşılmaktadır. Sultanların yakınında yer alan görevliler de kendilerine verilen rüşvetle aracılık yapmakta idiler.

Selçuklu vezirleri de rüșvet almıșlardır. Nizâm el-Mülk beș kez rüşvet almıştur. Bir devlet adamı olarak bir Siyaset-nâme yazarının rüşvet alması pek yerinde bir davranış gözükmüyor. Nitekim o eserinde birçok müesseseye fasıllar ayırmasına ve örnekler vermesine rağmen, rüşvet konusu üzerinde kanaatimce pek durmamıștur. O Siyaset-Nâme (Hazırlayan: M. A. Köymen, Ankara 1999, Trk.trc.s.45)'de, tespit edebildiğimiz kadarıyla, doğrudan bir yerde rüşvetten bahsetmektedir, Nizâm el-Mülk müşriflerin maaşlarıyla ilgili olarak, "onlara iş dolayısı ile gerekli olan Beytü'l-maldan versinler ki, onlar için hıyanet yapmaya ve rüşvet almaya hacet kalmasın. Onlar doğru hareket etmenin faydasını görsünler".

Vezirlik ve memuriyetlere bazen rüșvet ile tayinler yapılmıştur. Vezir olmak için mutlaka rüşvet vermek gerekiyor muydu?. Ancak bütün vezir tayinlerinde böyle bir olay tespit edilemediğinden bunu bir gelenek olarak kabulü mümkün görülmüyor.

Öte yandan kendilerine bir zarar gelmesini önlemek veya bir olay nedeniyle kızan sultanın affını sağlamak isteyenlerin başvurdukları son çare belki de rüşvet idi.

Bir șehir veya kalede kuşatılanlar da bazen verdikleri rüşvet ile muhasaradan kurtulmağa muvaffak olmuşlardır.

Metin içindeki örneklerde görüldüğü üzere rüşvet sadece bir menfaat karşılığında verilmekle sınırı kalmıyor, insan hayatını tehlikeye sokabilecek sonuçlara sebep olabiliyor veya insanları ölümden kurtarabiliyordu.

Düşmanlara karşı savaşmaları sağlamak için bazı topluluklara da rüşvet verilmekte idi. Bu yolla rüşvet bir ölçüde bir hükümdarın yerini sağlamlaşturırken, bir diğerinin mücadeleyi kaybetmesine yol açıyordu. 
Unvan alabilmek maksadıyla rüşvet teklif edenler de vardı. Emîrliğîn başına geçmek için rüşvet veren vassallar da bulunmaktaydı. Dedikoduları önlemek maksadıyla da rüşvet veriliyordu. Kudretle yöneticiler bir bahaneyle rüşvet isteyebiliyordu.

Bir tahsildar Oğuzlar'dan rüşvet alacağını ümit etmiş, ancak bu rüşvet verilmemiş ve onların mücadelesi Sultan Sencer'in esir edilmesiyle son bulmuştu (1153). Böylece bir tahsildarın Oğuzlar'dan rüşvet almak istemesi belki de Büyük Selçuklu Devleti'nin yıkılmasına sebep olayların başlangıcı olmuştu.

Tespit ettiğimiz olaylar bakarsak kaynaklarda zikredilen rüşvet teklifleri genelde Selçuklu toplumunun üst kademeler; sultanlar, eșleri, vezirler ve komutanlar ile ilgilidir. Alt derecedeki görevliler için örnek çok azdır. Bu tip görevlilerde kaynaklara aksetmeyen rüşvet olaylarına karışmış olmalıdırlar. Özellikle devletlerin çöküş dönemlerinde rüșvet olayları muhakkak çoğalmıştır. Ancak bunları tespit etmek, kaynaklarda zikredilmediği sürece oldukça zordur. 